NBER WORKING PAPER SERIES

\title{
FINTECH AS A FINANCIAL LIBERATOR
}

\author{
Greg Buchak \\ Jiayin $\mathrm{Hu}$ \\ Shang-Jin Wei \\ Working Paper 29448 \\ http://www.nber.org/papers/w29448
NATIONAL BUREAU OF ECONOMIC RESEARCH
1050 Massachusetts Avenue
Cambridge, MA 02138
November 2021

We thank Ant Group for data support. We are grateful to Zhenhua Li, Zhiyun Cheng, Fang Wang, Jian Hou for facilitating the data and Shu Chen for her excellent research assistance on data processing and analysis. We thank Pengfei Han, Yi Huang, Yiping Huang (discussant), Zhangkai Huang, Xiaoyan Lei, Laura Xiaolei Liu, Xiaomeng Lu (discussant), Danqing Mei (discussant), Jun Pan, Alberto Rossi (discussant), Yan Shen (discussant), Zheng (Michael) Song, Yang Su, Stijn Van Nieuwerburgh, Haotian Xiang, Kairong Xiao, Bernard Yeung, Yao Zeng (discussant), Conson Yingguang Zhang, Xiaoyan Zhang, Haoxiang Zhu, as well as conference and seminar participants at the ABFER and BFI-China Capital Market Development Webinar, China Financial Research Conference (CFRC), China International Conference in Finance (CICF), China International Conference in Macroeconomics (CICM), Columbia Macro Lunch, Luohan Academy, NBER Chinese Economy Working Group Meeting, Peking University GSM Finance Webinar, Peking University NSD Faculty Seminar, and the Peak Initiative of Digital Finance of Open Research for their helpful suggestions and comments. All errors are our own. Wei is a member of the Academic Advisory Council of Luohan Academy, a think tank associated with the Alibaba Group. This research project receives no funding from Alibaba or or any other sources other than the authors' university research budget. The views expressed herein are those of the authors and do not necessarily reflect the views of the National Bureau of Economic Research.

NBER working papers are circulated for discussion and comment purposes. They have not been peer-reviewed or been subject to the review by the NBER Board of Directors that accompanies official NBER publications.

(C) 2021 by Greg Buchak, Jiayin Hu, and Shang-Jin Wei. All rights reserved. Short sections of text, not to exceed two paragraphs, may be quoted without explicit permission provided that full credit, including $\odot$ notice, is given to the source. 
FinTech as a Financial Liberator

Greg Buchak, Jiayin Hu, and Shang-Jin Wei

NBER Working Paper No. 29448

November 2021

JEL No. E21,E42,E43,E44,E52,E58,G21,G28,G51

\begin{abstract}
$\underline{\text { ABSTRACT }}$
A binding interest rate cap on household savings is a common form of financial repression in developing economies and typically benefits banks. Using proprietary data from a leading Chinese FinTech company, we study Fintech's role in ending financial repression in China through the introduction of a money market fund with deposit-like features available through an more exposed to FinTech see greater deposit outflows. Importantly, exposed banks respond to facilitates a bottom-up interest rate liberalization.

Greg Buchak

Graduate School of Business

Stanford University

655 Knight Way

Stanford, CA 94305b

buchak@stanford.edu

Jiayin $\mathrm{Hu}$

National School of Development

Peking University

5 Yiheyuan Rd

Beijing, China 100871

jyhu@nsd.pku.edu.cn

\author{
Shang-Jin Wei \\ Graduate School of Business \\ Columbia University \\ Uris Hall 619 \\ 3022 Broadway \\ New York, NY 10027-6902 \\ and NBER \\ shangjin.wei@columbia.edu
} already widely-adopted household payment platform. Cities and banks whose depositor base is FinTech competition by offering competing products with market interest rates. FinTech thus 


\section{Introduction}

Financial repression-regulations that keep the interest rate on household savings below the unconstrained value—is a widespread phenomenon and a cause of underdevelopment (McKinnon et al., 1973; Shaw, 1973) in the developing world. Policies that ameliorate financial repression are therefore important for improving aggregate economic efficiency. However, while removing financial repression may enhance aggregate welfare, some market participants may be made worse off once these distortions are eliminated. Thus, politically connected incumbents may impede liberalization, making top-down, politically-led reforms difficult. In particular, by capping interest rates for household deposits, financial repression may reduce the cost of capital and increase profitability for large commercial banks with both market power and political power. Anticipating this, these banks-and the regulators concerned with their profitability and stability—may resist efforts to uncap rates.

In this paper, we examine an alternate pathway for financial liberalization in the context of China: bottom-up liberalization driven by financial innovation outside the repressive regulatory framework. We ask how effective such a market-driven approach is in effecting liberalization and how incumbent banks respond to it. Before 2013, bank deposits constituted a vast majority of Chinese households' liquid assets, and these deposits were equivalent to roughly 30 percent of China's GDP in size ${ }^{1}$. Crucially, these deposits were subject to an interest rate cap-similar to Regulation Q in the United States-that constrained interest rates far below the unconstrained market rate on similar, unregulated funding sources. Incumbent banks with significant market power had little incentive to push for policy reforms or engage in regulatory arbitrage for fear of cannibalizing their own cheap deposit financing.

Competition appeared from outside the traditional banking system in June 2013, when Alipay, already a trusted, dominant FinTech player in payments, introduced Yu'ebao, a money market fund (MMF) product. Unlike traditional banks, Alipay did not rely on a large, low-rate deposit base for funding, and so did not stand to lose from disrupting the existing deposit regime. Moreover, unlike typical money market funds, Yu'ebao offered $\mathrm{T}+0$ liquidity, which when coupled with Alipay's payment system, allowed investors to use their Yu'ebao shares to effect transactions in both online and offline shopping as they would with demand deposits. In contrast to demand deposits, Yu'ebao's interest rate

\footnotetext{
${ }^{1}$ By the end of 2012, household deposits reached 40.6 trillion yuan, with 15.8 trillion yuan in the form of demand deposits and 24.8 trillion yuan in time deposits, according to the Sources \& Uses of Credit Funds of Financial Institutionsby Sectorsreleased by the People's Bank of China. China's GDP in 2012 was 53.9 trillion yuan, as released by its National Bureau of Statistics.
} 
was not subject to the binding interest rate cap and instead offered market interest rates. Thus, Yu'ebao provided both deposit-like transaction services and interest rates unrestrained by an artificially low cap, available through a widely adopted and trusted payment system. Yu'ebao proved immensely popular almost immediately: It reached 40 million customers and over 185 billion yuan (around 28 billion USD) in assets under management within six months of its launch. Other FinTech companies followed suit and introduced similar products.

Before Yu'ebao, Chinese households had essentially no exposure to money market funds, with total investments into money market funds totaling less than $1 \%$ of bank household deposits. With the introduction and growth of Yu'ebao and similar products, the aggregate market share of bank deposits relative to money market funds declined as household savings flowed into these products. Flows from banks into these products were not uniform: There was significant heterogeneity in deposit customers' propensity to adopt Yu'ebao, with some banks' deposit bases concentrating in cities where Yu'ebao uptake was high, and other banks' deposit bases concentrating in cities where Yu'ebao uptake was low. We exploit this variation to show that banks with the most exposed deposit bases saw the greatest deposit outflows into Yu'ebao. Consistent with the tight connection between Alipay's consumer platform and Yu'ebao, primarily household demand deposits were affected, while other categories of deposits, such as household time deposits and firm deposits of all types, were unaffected.

As household deposits left the banking sector for the FinTech competitor, banks' endogenous response to competition led to further financial liberalization. We show that banks with greater exposure to Yu'ebao flows were more likely to invest in defensive innovation. In particular, the most exposed banks launched their own Yu'ebao-like money market funds to compete with Yu'ebao. These off balance sheet products circumvented the repressive interest rate cap on household deposits and passed higher interest rates to household savers. Importantly, with the launch of these products, banks appeared able to resist the most dire predictions regarding their profitability and stability: we find little evidence of reduced revenues, increased costs, or increased lending to risky customers. Thus, while Yu'ebao's rise did siphon deposits away from banks, these competitive pressures caused the most exposed banks to innovate, rather than suffer losses to their profitability and stability. The ultimate effect appears to be financial liberalization that benefited households without markedly worse bank performance.

Our results show that greater Yu'ebao penetration is associated with increased deposit outflows and financial innovation. To make the argument that Yu'ebao exposure had a causal impact as opposed to 
the reverse (i.e., that for other reasons, deposits left the local banking system and flowed into a natural alternative, Yu'ebao), we introduce two instrument variables strategies. We look for instruments that predict Yu'ebao uptake without being related to unobservable factors that would cause deposit outflows for other reasons, i.e., bank health. First, we utilize the city-level penetration of the Alipay payment platform prior to the introduction of Yu'ebao. The instrument's relevance results from the fact that Yu'ebao adoption is less costly for users already using the platform for other purposes. Moreover, the instrument addresses the primary identification concern of simultaneity because users had already adopted the Alipay platform before it offered a substitute for bank deposits. ${ }^{2}$

As a second instrument, we utilize the geographical distance from the Alipay's headquarter in the city of Hangzhou. This exploits the gradual spread of Yu'ebao: the roll-out was more convenient for Alipay in markets closer to its headquarters. As with the case of pre-Yu'ebao Alipay adoption, the instrument overcomes the primary identification concern because Ali's headquarters (and therefore any market's distance from it) was established in 1999, far predating Yu'ebao's introduction in 2013. With these instruments, we find qualitatively similar results. Our interpretation of these findings is that FinTech, and in particular, the introduction of Yu'ebao, aided in reducing financial repression in China.

Our results help shed light on explanations for the popularity of FinTech money market funds among Chinese households. A salient potential explanation is regulatory arbitrage: these money market funds avoid China's binding interest rate cap on bank deposits, thus offering a close substitute to bank deposits at more favorable interest rates. While this offers a potential explanation, especially post-Yu'ebao, the explanation fails to explain the slow growth of the money market fund industry prior to Yu'ebao's introduction: Money market funds offering above-ceiling interest rates existed pre-Yu'ebao, yet uptake was low. While these products did not offer the transaction services available from bank deposits and eventually from Yu'ebao, banks could have, in principle, offered these features on their own and aggressively marketed these products. However, they did not. We posit that incumbent banks in China chose not to undertake this regulatory arbitrage before Yu'ebao's introduction partly because owing to their considerable concentration, would have cannibalized their own, lower interest rate deposit base.

It is important to point out that lack of familiarity and trust with mutual funds by Chinese households before the introduction of Yu'ebao is also important in this story. This is not surprising in a bank-

\footnotetext{
${ }^{2}$ Additionally, we run placebo tests by varying the timing of the treatment to make sure that the effect corresponds to the launch of Yu'ebao and not from an unobserved association between Alipay take-up and the financial health of banks.
} 
centric financial system. The high barriers to adoption of mutual fund investment before Yu'ebao translate into a high degree of stickiness of bank deposits (low sensitivity to interest rate). Banks take advantage of this deposit stickiness and found no reason to market money market products to their deposit customers. [For wealthy and financially sophisticated customers, banks did offer "wealth management products" with market returns. However, these products typically had a high level of minimum investment amounts far in excess of what the typical Chinese household possessed in savings. ${ }^{3}$ Thus, while regulatory arbitrage offers a partial explanation of Yu'ebao-like products' popularity, it is important to consider the pre-Yu'ebao competitive dynamics that may have impeded their take-up.

Unlike a standard money market fund, Yu'ebao was connected to Alipay, a near ubiquitous presence in China that had been in existence for a decade by then. This meant that Yu'ebao came with significant brand recognition and trust. Additionally, its connection through the Alipay app meant that it was familiar and accessible to average Chinese households who may have lacked the financial sophistication to use another firm's offering.

The final hypothesis concerns household demand for money-like claims, and the product features that make FinTech money market funds able to satisfy this demand. China indeed has a large demand for safe, money-like assets: According to the China Household Finance Survey (CHFS) in 2011, over $75 \%$ of household financial assets are held in the form of bank deposits and cash $(58 \%$ and $18 \%$, respectively). Payment services, which used to be dominated by commercial banks, are therefore extremely important. Historically, traditional banks benefited from the deposit interest rate ceiling and lacked incentives to offer deposit substitutes with market interest rates. The emergence of Yu'ebao, with its bundled payment services, created a directly competing product for traditional demand deposits' transaction services by satisfying households' demand for money-like claims. By introducing these features, products that offered similar transaction and liquidity services allowed FinTech money market funds to compete directly with bank deposits, thus organically undermining the artificially low interest rate cap. However, as we show, the arrival of FinTech payment services alone was not sufficient to pull deposits from banks: Even areas with high FinTech payment penetration did not see significant bank outflows until Yu'ebao itself was launched. This highlights the confluence of factors ultimately behind the rapid rise of Yu'ebao: the bundling of a payment and savings vehicle, available on an ubiquitous platform, in

\footnotetext{
${ }^{3}$ Wealth management products typically had a minimum investment amount of at least 50,000 RMB, much higher than the 6,000 RMB median financial assets held by Chinese households as of 2011. In fact, in the time period around Yu'ebao's introduction, over $99 \%$ of Yu'ebao purchases fell below the 50,000 RMB cutoff that would have been required for a bank WMP.
} 
the context of broader financial repression.

Our paper contributes to several strands of the literature. At a high level, we begin with the observation that understanding how FinTech affects depositors' choices and traditional bank performance is important for designing macro-prudential policies. While the potential impact of FinTech has been of intense academic interest, as in Philippon (2016), Claessens et al. (2018), and Goldstein et al. (2019), several questions remain concerning the impact of FinTech competing with traditional banks and the macroeconomic implications of that competition. Our paper speaks to many of these questions.

First, our paper provides empirical evidence on the competitive dynamics between FinTech and traditional banks in the retail deposit market. Extensive literature has examined how banks and FinTech lenders compete (e.g., Navaretti et al., 2018; Thakor, 2020) and their competition across many product markets, for instance, lending and use of data (for instance, Buchak et al., 2018b; Tang, 2019; Fuster et al., 2019; Berg et al., 2020), payments (see Parlour et al., 2020; Jack and Suri, 2014) and investment (such as D'Acunto et al., 2019; Hong et al., 2019). Our paper joins Xiao (2020) and Ma et al. (2020) in examining the competitive structure for deposit-like products. Additionally, our paper contributes to the literature on banking theory and economies of scope by highlighting important synergies between payment and other bank services (e.g., wealth storage and lending) as in Parlour et al. (2020) and Jack and Suri (2014). Interestingly, in our setting, these synergies are most consequential among non-banks, and raises questions regarding the fundamental "specialness" of banks, similar to, e.g., Jiang et al. (2020). Beyond the traditional synergies between traditional bank-like services, our paper points to important synergies between the traditional, narrowly defined financial services (payment, investment, lending) and other financial services like e-commerce.

Second, our paper examines how the arrival of FinTech induces banks themselves to catch up in terms of introducing competing products. While many papers have examined the competitive effects of FinTech, few (such as Boot, 2017; Vallee and Zeng, 2019) have examined traditional banks' response. We show that contrary to the concerns of many regulators, banks' endogenous technological response enables them to avoid the worst-case outcomes to their profitability by introducing their own competing FinTech products. Our paper further connects to papers examining the broad trend of migration of traditional bank activity away from regulated depository institutions and towards less regulated shadow banks. Gennaioli et al. (2013) and Moreira and Savov (2017) model this phenomenon; Buchak et al. (2018a), Jiang et al. (2020), and Zhang (2021) study this question empirically in the context of residen- 
tial mortgage lending in the United States. Our paper contributes by examining the migration of bank liabilities (as opposed to assets) outside of the regulated system (deposits) and towards a less regulated sector (money market funds). Acharya et al. (2020) analyzes the competitive impact of the expansion of big state-owned banks on the issuance of wealth-management products among small- and mediumsized banks in China. Our results highlight the significant rent that banks possessed before the competition from FinTech and how the endogenous response of the banks-introducing their own $\mathrm{T}+0$ and shadow-banking products and improving efficiency elsewhere - can offset the losses they face due to competition.

Finally, our setting offers an important lens into how the competitive interaction of FinTech and traditional lenders leads to significant macroeconomic changes. Prior to the explosive growth of Yu'ebao and banks' reactions to it, financial repression in China constrained the rates that households could earn on bank transaction deposits. Highlighting a bright side of FinTech shadow banking, Yu'ebao created space for bottom-up interest rate liberalization in a context where top-down reform may have been difficult due to political economy reasons (including resistance from banks). Beyond improving the welfare of household finance and risk-taking (for instance, Hong et al. (2020)), these changes have the potential to lead to higher allocative efficiency. Our paper echoes with Brunnermeier et al. (2017), Chen et al. (2018), Song and Xiong (2018), Xiong (2018) and Brunnermeier et al. (2020) by demonstrating the potential benefits of shadow banking given the sub-optimal allocation in the formal financial system driven by distortive regulations.

Our paper proceeds as follows: Section 2 introduces the institutional background of FinTech and banking in China. Section 3 details the data and presents our empirical methodology. In Section 4, we show city-level regression results examining how FinTech payment contributes to the growth of FinTech money market funds like Yu'ebao. In Section 5, we examine the impact of Yu'ebao on bank deposit growth and banks' strategic response. Section 6 investigates the impact on bank balance sheet outcomes. We discuss our findings and conclude in Section 7.

\section{Institutional Background on China's Financial System}

This section provides a brief background of financial repression in China prior to Yu'ebao, the competitive landscape of the Chinese banking industry, and the development of FinTech in the retail market. 


\subsection{Financial Repression and Interest Rate Regulation}

Financial repression is a common phenomenon in many countries, especially in the developing world. A major element of financial repression in China involves household demand deposits. The banking industry plays a dominant role in China's financial system, accounting for more than $80 \%$ of credit and households' financial assets. Bank interest rates were once strictly regulated in China, where the central bank imposed both a floor and a ceiling on the deposit and lending interest rates. Some aspects of interest rate restrictions have seen relaxation since 2004, including lifting of a floor on the deposit interest rate and a ceiling on the lending interest rate. The lending floor was liberalized almost ten years later in July 2013. In comparison, a ceiling on deposit interest rates has proved to be stubbornly difficult to remove. This eventually was phased out in October 2015. Our paper will make the point that FinTech has played an instrumental role in ending this particular dimension of financial depression. There is still unofficial "self-disciplinary organization" that monitors interest rates offered by commercial banks, meaning that deposit rates should not be regarded as completely unregulated even after the ceiling was officially lifted. Still, the availability of mutual fund products through FinTech platforms has greatly reduced the impact of the interest rate restrictions on households.

Figure 1 shows both the regulated deposit rates and the interest rate for a similar but unregulated market, the 3-month Shanghai Inter-Bank Offered Rates (SHIBOR, the most commonly used reference rate in China), between 2003 and $2018^{4}$. We emphasize three key features of regulated interest rates and market interest rates: First, the interest rate ceilings on deposits almost always fall below market interest rates. The demand deposit interest rate ceiling is approximately $0.35 \%$ and the 3-month time deposit ceiling ranges from $1.8 \%$ to $3 \%$. During the same period, SHIBOR increased from $2 \%$ to over $6 \%$, later hovering around $4 \%$, far above the capped deposit rates.

Second, the interest ceilings seldom change. The central bank controls the timing and level of benchmark rates and ceiling requirements, and the central bank has changed the ceiling fewer than ten times in more than twenty years, despite the central government's efforts to liberalize interest rates. Hence, despite daily fluctuations in the uncapped SHIBOR, deposit interest rates show essentially no sensitivity to market conditions.

Third, the yield of Yu'ebao co-moves with SHIBOR rather than following with the deposit rate ceil-

\footnotetext{
${ }^{4}$ The interbank market interest rate in China was already liberalized in 1996, seven years before the first money market fund was launched in China in 2003.
} 
ing. For instance, during its first two years, Yu'ebao provided an average of $2 \%$ higher yield than 3month time deposits, and a strikingly 5\% higher yield than demand deposits. Hence, money market funds are able to provide and pass through market yields, providing incentives for investors to move money from banks to money market funds during monetary tightening.

\subsection{High Concentration and Lack of Reform Incentives in the Banking Industry}

Deposits are a major source of bank funding. Panel A of Figure 2 plots each bank's reliance on deposit funding against its branch market share as of May 2013. Deposits account for over $60 \%$ of the interestbearing liabilities for the vast majority of banks. This ratio increases to over $80 \%$ for state-owned banks. Thus, banks with the greatest market share are among the most reliant on deposits for funding. Interest rate caps therefore lower the cost of the most important source of funding for China's largest banks. Hence, these large banks do not have strong incentives to support top-down interest rate liberalization.

Importantly, state-owned banks are politically resourceful: top officials of regulatory authorities including the People's Bank of China (PBOC), China Banking and Insurance Regulatory Commission (CBIRC), and China Securities Regulatory Commission (CSRC) often come from large state-owned banks. Hence, state-owned banks can have both tremendous direct and indirect influence over regulation policies and strong incentives to resist interest rate liberalization.

\subsection{Weak Presence of Money Market Funds Prior to FinTech Innovation}

Money market funds do not take deposits and are not constrained by interest rate ceiling regulations that commercial banks are subject to. Therefore, money market funds have incentives and capabilities to offer higher yields to compete for depositors. However, the mere possibility of regulatory arbitrage alone does not naturally lead to a more liberalized financial system. The money market fund industry in China, while providing uncapped market yields, experienced only modest growth and remained almost invisible to households in terms of relative size to bank deposits since their inception in 2003.

As shown in the upper panel of Figure 3, the absolute and relative sizes of the money market fund industry compared to the size of household deposits in traditional banks remained at a low level since 2003, when the first money market fund was founded in China. Importantly, these money market funds did not possess the deposit-like $\mathrm{T}+0$ real time redemption features that made them close substitutes 
for bank deposits. Given banks' significant deposit market concentration, they had little incentive to introduce or innovate in unregulated products that could cannibalize their inexpensive deposit funding.

In consequence, the money market fund industry did not grow substantially for ten years until 2013, when Yu'ebao was introduced. Yu'ebao combined higher money market fund yields with the reputation and convenience of payment services, including $\mathrm{T}+0$ redemption features ${ }^{5}$ that offered a close substitute to bank deposits. This product, with demand-deposit-like features and uncapped money market-like yield brought competitive pressure to traditional banks that until then had dominated the household deposit market.

\subsection{FinTech Money Market Funds Create Deposit-Like Products}

FinTech changed the landscape in the payment industry. Digital payment through scanning a QR code now dominates payments in China. Alipay, incorporated in 2004, is the leading third-party digital payment platform in China. According to iResearch ${ }^{6}$, as of 2013Q2, Alipay led the web-based thirdparty payment market with a market share of $48.7 \%$, while Tencent's Caifutong ranked second with $20 \%$, followed by UnionPay with $10 \%$. Alipay's market dominance increased to a stunning $60.7 \%$ if we look at the then-burgeoning third-party mobile payment market.

Alipay launched Yu'ebao in $2013 .{ }^{7}$ Yu'ebao was the first product combining FinTech payments with a money market fund ${ }^{8}$ and was uniquely designed for and sold on Alipay. Compared the money market funds and wealth management products then available from banks, Yu'ebao had three innovative features: T+0 real-time unlimited redemption ("real-time redemption"), instant and seamless conversion from redemption of the money market funds to the use of the proceeds for payment on Alipay (hereafter "share payment"), and essentially no minimum investment amounts. First, the real-time redemption feature allows investors to receive fund redemption within seconds. Second, the share payment function enables investors to use Yu'ebao shares to pay for purchases of goods or services both online and offline. FinTech payment greatly enhanced the liquidity of Yu'ebao for those who owned shares and enabled it

\footnotetext{
${ }^{5}$ The first exchange-traded money market fund with the $\mathrm{T}+0$ feature was launched by Huitianbao in October 2012. As indicated in the name, this type of T+0 money market fund is subscribed and redeemed in the exchange and is therefore limited to stock market account holders. This type of money market funds is vastly different from Yu'ebao, which provides free $\mathrm{T}+0$ services for all investors with an Alipay account for daily expenditures.

${ }^{6} \mathrm{http}: / /$ news.iresearch.cn/zt/207283.shtml.

${ }^{7}$ In May 2013, Tianhong Fund announced that it would cooperate with Alipay to launch Yu'ebao by providing real-time fast redemption and payment using money market fund shares starting on June 14, 2013.

${ }^{8}$ This focus on the bundling of money market fund and payment services distinguishes our paper from those examining the impact of FinTech distribution platforms without payment features, for instance, Hong et al. (2019).
} 
to become a close substitute to bank demand deposits. Third, "no minimum investment" means that Yu'ebao is accessible to virtually all households (whereas a high minimum investment requirement associated with the "wealth management products" prior to Yu'ebao made them essentially irrelevant for most households).

Yu'ebao spawned the launch of products combining money market funds with real-time redemption features, known popularly in China as bao products. Administering a bao requires combining payment technology with a wealth-management product, which is difficult for companies that are not commercial banks or FinTech companies. We focus on bao products distributed either by FinTech ("FinTech bao", led by Yu'ebao) and commercial banks ("bank bao", which sprang up after the launch of Yu'ebao).

\subsection{Resistance and Strategic Response from Traditional Banks}

Around the time that Yu'ebao launched in June 2013, a liquidity crunch drove the wedge between the market interest rate and the capped deposit rate, which was unchanged, even higher. This spike is illustrated in Figure 1. Yu'ebao benefited from this large divergence, further fueled the popularity of Yu'ebao relative to bank deposits. The commercial banking industry mounted significant resistance and pushback against Yu'ebao's popularity and the threat that it and other baos posed to their business models. In the media, reports appeared calling Yu'ebao "the vampire sucking blood from banks," because the majority of Yu'ebao assets were negotiated deposits with banks, paying well above the capped deposit rate. Some senior officers of the large state-owned banks, who served as "zhengxie weiyuan" (members of the Chinese People's Political Consultative Conference, CPPCC), proposed to the central government to impose restrictions on FinTech during the joint annual sessions of the People's Congress and the Chinese People's Political Consultative Conference in March 2014, the largest annual political event in China.

FinTech development also had its symphasizers in the government: both Premier Li Keqiang and central bank governor Zhou Xiaochuan would not want to ban Yu'ebao. As the banks were not successful in lobbying for a ban, they started to respond differently. While some banks placed restrictions on the ability of their deposit customers to use Yu'ebao, ${ }^{9}$ others began to offer Yu'ebao-like retail products

\footnotetext{
${ }^{9}$ Such as a daily limit on the amount of money depositors are able to move from their bank accounts to Yu'ebao. Some bank headquarters ordered their branches not to deal with Yu'ebao and other money market funds. See, for instance, the news report in 2014 (http:/ / finance.sina.com.cn/money/bank/bankvsyuebao/). These measures could alienate their customers and potentially drive them towards other banks that maintain a relationship with Alipay/Yu'ebao.
} 
through cooperation with other money market funds. Once some banks offer bao products, other banks feel the pressure to do the same.

The emergence of Yu'ebao's is followed by a rapid growth of the money market funds. Panel C of Figure 3 plots the number of $\mathrm{T}+0$ money market funds distributed by banks and the number of unique banks distributing T+0 money market funds over time. Notably, banks only began to offer money market funds with $\mathrm{T}+0$ real-time redemption after the introduction of Yu'ebao in June 2013. Following this date, the number of unique banks offering $\mathrm{T}+0$ money market funds rapidly increased to more than 20 in 2014, subsequently doubling by the end of 2016. The total number of bank bao products follows a similar pattern at higher levels, meaning that individual banks were offering multiple bao products. In subsequent sections, we will make the case that the emergence of Yu'ebao has caused the growth of the money market funds and effectively spelled the end of financial repression for Chinese households.

\section{Data and Empirical Methodology}

This section outlines our data sources and empirical methodology. Broadly, from account usage and flow data, we calculate measures of Yu'ebao and Alipay use, as well as Yu'ebao and deposit flows at the city and bank levels. Our empirical methodology then examines how outcomes at cities and banksprincipally deposit flows, bank profitability, and bank innovation-vary cross-sectionally among cities and banks with exposure to Yu'ebao.

\subsection{Data}

We combine three sources of data: (1) data on fund flows and digital platform from Alipay, (2) data on Chinese banks and money market funds, and (3) city- and regional-level economic data, which serve as important control variables in our analyses.

Alipay data. Our data on Yu'ebao and Alipay come from Ant Group (formerly Ant Financial), the parent company. Alipay was launched in 2004 and has since been the largest third-party digital payment tool in China. Yu'ebao, the money market fund associated with Alipay, was launched in June 2013 and possesses many important features that distinguish it from existing money market fund products, as discussed earlier. 
Our unique data from Ant Group include the city-month-level number of active Yu'ebao and Alipay users. With this data we are able to track the penetration ratios of both Yu'ebao and Alipay, and the number of active users on each. Additionally, we observe transaction-level Yu'ebao purchase records starting from its launch date. Since Yu'ebao is embedded in Alipay, investors must first register to become Alipay users if they have not done so. Critically for our research, we observe the time stamp, the Yu'ebao purchase amount, whether it comes from a bank card, and the user's residence city. We use this information to aggregate transaction-level purchases to the city-month level and focus on cumulative fund flows into Yu'ebao and the users' net Yu'ebao position as of May 2014, i.e., twelve months after its launch in June 2013.

Bank data. Our data on commercial banks and their registered branches come from CBIRC (formerly CBRC and (IRC), the official regulatory authority of the banking industry in China. Banks are required by the law to obtain CBIRC's approval before opening a new branch. The registration form lists each branch's full name, full address, head office name, approval date, and exit date. We merge this branch data with the list of commercial banks and the list of 337 prefecture- and above level cities. We obtain the number of active branches at the bank-city-month level.

We remove banks without any branches and those founded after December 2011 from sample. Additionally, for data availability reasons, we restrict the sample of banks to state-owned ("big"), joint-stock ("gufen"), and city commercial banks while excluding rural commercial banks, village banks ("cunzhen"), privately-owned banks ("minying"), and foreign banks, all operating in urban areas. ${ }^{10}$ The refinement leaves 145 banks operating 138,231 branches, representing more than $70 \%$ of bank branches in China. It is important to note that while we focus on the 145 largest banks, this sample contains significant heterogeneity in bank size, with the state-owned banks being significantly larger than many of the other, much smaller banks in our sample.

We merge this sample of banks with information on commercial banks from WIND, CSMAR, and RESSET, the most comprehensive financial and economic data sets in China. The bank-level data compilation includes: (1) basic registration information, such as the full name, inception date, bank type, and headquarters city; (2) bank-year-level deposits data, including eight subcategories, namely, demand vs. time deposits, household vs. firm deposits, household demand and household time deposits, firm demand and firm time deposits; (3) bank balance sheet data, including net interest margin (NIM), cost-

\footnotetext{
${ }^{10}$ Focusing on urban areas makes the bank sample consistent with the Alipay sample, which links users to urban areas.
} 
to-income ratio, bad loan ratio, risky asset ratio, and profits, revenues, and costs broken down by core and interest-based business units.

We further complement our bank-level data using wealth-management products data from WIND. The wealth management product data provides detailed product-level information on each wealth management product issued by commercial banks, including the product name, issuing date, issuing bank, investment type, target clients, investment threshold, expected yield, realized yield, and guarantees.

Money market fund data. We hand-collect information on bank bao products from fund company announcements. We identify the exact dates when each bao product was launched by searching key words in all money market fund announcements compiled by WIND. ${ }^{11}$ The key words include variations of "T+0 fast redemption" and exclude words such as "halt", "pause", "adjust", and "change", so that we could date the first announcement of a bao-type product. Since the titles of the announcements are already informative, we restrict the key word search to announcement titles. The key word search focuses on the period from 2003, the inception year of the first money market fund in China, to 2017, four years after the launch of Yu'ebao when the regulatory authority started to restrict the T+0 redemption practice in the money market fund industry. The search yields the precise date when a bank offers its first bao-type product. We cross-check these dates with news releases on banks' official websites and in the media.

City-level and macro economic data. We obtain city-year-level macro data, such as GDP and population, from CSMAR and WIND. We combine these data with administrative city-level information, such as full name, province, longitude and latitude, available from the Ministry of Civil Affairs and the National Bureau for Geographics. The benchmark policy interest rates come from the PBOC. The interbank market rate SHIBOR comes from chinamoney.com, the official website for the China Interbank Market.

\footnotetext{
${ }^{11}$ WIND is the most comprehensive database on financial and economic information that is widely used by practitioners and researchers of Chinese financial markets. WIND and other database also provide a list of bao products, but the launching dates of bao products are missing. Instead, they use the founding date of the money market fund behind each bao product, which could be vastly different from the actual launching date of bao product. For instance, a money market fund founded in October 2005 started to offer $\mathrm{T}+0$ redemption through a bank in May 2014. Hence, it is important to use bao launch announcement dates rather than money market fund founding dates.
} 


\subsection{Key Variable Definitions}

City-level variables: The main independent variables of interest are the penetration ratio of Yu'ebao, and as instrumental variables, the penetration ratio of the Alipay platform more broadly, and the distance of the city from Alipay's headquarters in Hangzhou. The Yu'ebao (or Alipay) penetration ratio is defined as the number of active users of Yu'ebao (or Alipay) in a geographical region divided by the local population, at a monthly frequency. The Hangzhou distance of a city is city $c$ 's distance to Hangzhou. In particular,

$$
\begin{aligned}
E_{c t}^{Y E B} & =\frac{U \operatorname{sers}_{c t}^{Y E B}}{\text { Population }_{c t}} \\
E_{c t}^{A L I} & =\frac{\text { Users }_{c t}^{A L I}}{\text { Population }_{c t}} \\
H Z \text { Distance }_{c} & =\text { Distance of } c \text { to Hangzhou }
\end{aligned}
$$

This yields a city-level monthly time series that begins in January $2012 .{ }^{12}$ For confidentiality reasons, Ant Group normalizes the raw penetration ratios to an index, using the values in January 2014 in Hangzhou as the benchmark $\left(E_{H Z, J a n 2014}^{Y E B}=E_{H Z, J a n 2014}^{A L I}=100\right)$. Unsurprisingly, $E_{c t}^{Y E B}$ and $E_{c t}^{A L I}$ are $95 \%$ correlated, suggesting a striking synergy between the use of Yu'ebao and the use of the Alipay platform more broadly.

Our identification exploits geographical variation in Alipay and Yu'ebao exposure. Figure 4 shows the variation in city-level FinTech penetration graphically, with Panel A showing Yu'ebao penetration and Panel B showing Alipay penetration as of Dec 2013 and May 2013, respectively. We focus on Alipay penetration fixed as of May 2013, one month before Yu'ebao's introduction, and Yu'ebao penetration as of December 2013, six months after its launch.

Bank-level variables: We further exploit bank variation across several dimensions. First, using the bank branch network, we define the city's importance to the bank, $\omega_{b c t}$, as

$$
\omega_{b c t}=\frac{\# \text { Branches }_{b c t}}{\sum_{k} \# \text { Branches }_{b k t}}
$$

\footnotetext{
${ }^{12} E_{c t}^{Y E B}$ is identically zero prior to Yu'ebao's introduction.
} 
where $k$ sums over cities. A high $\omega_{b c t}$ indicates that a greater share of bank $b^{\prime}$ s branches are located in city $c$, which approximates a larger clientele base in city $c$ and, hence, a greater exposure to FinTech competition when city $c$ is penetrated.

We then aggregate Yu'ebao and Alipay exposure to the bank level as follows

$$
\begin{aligned}
E_{b t}^{Y E B} & =\sum_{c} \omega_{b c t} E_{c t}^{Y E B} \\
E_{b t}^{A L I} & =\sum_{c} \omega_{b c t} E_{c t}^{A L I}
\end{aligned}
$$

Intuitively, a bank with a high Yu'ebao (or Alipay) exposure is one with a large share of its branches in cities with many Yu'ebao (or Alipay) users. Other city-level variables, such as the distance to Hangzhou, GDP, and GDP growth rate, are aggregated to bank level following the same approach:

$$
X_{b t}=\sum_{c} \omega_{b c t} X_{c t}
$$

Where $X_{c t}$ includes, e.g., the log distance to Hangzhou, log GDP level, and GDP growth at the city level. For the cross-sectional analysis, we fix $E_{b}^{Y E B}$ to December 2013, $E_{b}^{A L I}$ to May 2013, and other city-level or bank-level controls to May 2013. ${ }^{13}$

\subsection{Empirical Design}

We study the impact of the launch of Yu'ebao across a number of outcomes: deposit flows, banks' competitive response, and ultimately, banks' profitability and risk-taking activities. The empirical design is similar in each case, so we detail our strategy here.

OLS specifications. The primary specification exploits variation in Yu'ebao penetration as of December 2013 to examine the impact of FinTech exposure on a number of outcome variables. In particular, at the city and bank levels, respectively, we regress:

$$
\begin{aligned}
& Y_{c}=\beta_{0}+\beta_{1} \log E_{c, 2013}^{Y E B}+X_{c}^{\prime} \beta+\epsilon_{c} \\
& Y_{b}=\beta_{0}+\beta_{1} \log E_{b, 2013}^{Y E B}+X_{b}^{\prime} \beta+\epsilon_{b}
\end{aligned}
$$

\footnotetext{
${ }^{13}$ This is non-trivial for Hangzhou distance because the bank branch network can change over time.
} 
where $Y_{c}$ and $Y_{b}$ are city-level or bank-level outcomes, which include deposit outflows and deposit growth rates. At the bank level, we also examine the financial performance variables, and the introduction of competing bao. ${ }^{14} X_{c}^{\prime}$ and $X_{b}^{\prime}$ represent a number of city- or bank-level controls, including GDP per capita, log GDP growth, log population, and an indicator for whether the city is a provincial capital. A notably absent control from our analysis is the level of deposit interest rates. While one might expect spreads between Yu'ebao and deposit rates to drive household responses, essentially all bank interest rates are constrained at the cap, and thus there is no cross-sectional variation. ${ }^{15}$

Observe further that our empirical design is cross-sectional in differences. By looking at city- or bank-level changes, we implicitly difference out time-invariant characteristics such as the baseline level of development of the city, or bank size, between June 2013 and May 2014. This is effectively equivalent to running a panel regression in levels with fixed effects. Due to the difference in difference approach, we are unable to identify the time-series aggregate effect of Yu'ebao's introduction on the amount of bank deposits.

Instrumental variable (IV) approach. Our aim is to examine how the entry of competing FinTech products causes changes at banks. A potential concern with our OLS approach is that adoption of Yu'ebao is caused by consumers wanting to exit banks and not the other way around. In other words, the concern is that we are picking up a reduction of consumer demand in the household deposit market that substitutes towards the money market fund investment market. The variation that we seek, rather, runs the other way: an exogenous shift in the availability of a competitor product that reduces the demand for household bank deposits. To address this endogeneity concern, we adopt two instrumental variable strategies that utilize pre-Yu'ebao Alipay penetration and the city's distance (or bank's branchweighted distance) from the Alipay headquarters in Hangzhou.

The justification for these instruments is that they shift consumers' access to Yu'ebao in a way unrelated to the local banking market. In the case of Alipay penetration, instrument relevance comes from the fact that adopting Yu'ebao is easier, more natural, and lower cost for users who already have the payment app to which Yu'ebao is connected, and offers the greatest convenience benefits for pairing payments and saving technology. Instrument exogeneity comes from the timing restriction: We use Ali-

\footnotetext{
${ }^{14}$ As a robustness check, we run the bao introduction specification as a hazard model, which we detail in a later section.

${ }^{15}$ In the US context, Ho and Ishii (2011) estimate own-price elasticity for deposits to be roughly 1 . The Yu'ebao interest rate at launch was higher than the capped interest rate by roughly 4 percentage points. While this led to a quantitatively large amount of flows from bank deposits into Yu'ebao, our empirical methodology cannot directly calculate the elasticity.
} 
pay penetration at a time well before the introduction of Yu'ebao, thus precluding any reverse causality related to shifting demand for household bank deposits. Additionally, the payment technology per se does not compete with bank deposits: FinTech payment users still need to associate bank cards with their Alipay accounts to make payments, and so the use of Alipay does not obviate the need for a bank account. The Hangzhou distance measure carries these ideas further back in time: The roll-out of Alipay was faster in cities near Ali's headquarter, which was fixed far predating the launch of Yu'ebao. Later in the paper, we further examine the validity of our IVs by using pre-Yu'ebao outcomes as dependent variables as a placebo test and find no statistically significant results, in support of the exclusion restriction.

The IV analogs to the OLS specifications for the city-level regression, (8), and the bank-level regression, (9), are as follows:

$$
\begin{aligned}
& Y_{c}=\beta_{0}+\beta_{1} \log \hat{E}^{Y E B_{c, 2013}}+X_{c}^{\prime} \beta+\epsilon_{c} \\
& Y_{b}=\beta_{0}+\beta_{1} \log \hat{E}^{Y E B_{b, 2013}}+X_{b}^{\prime} \beta+\epsilon_{b}
\end{aligned}
$$

where $\log \hat{E}^{Y E B}{ }_{c, 2013}$ and $\log \hat{E}^{Y E B}{ }_{b, 2013}$ are the predicted city- and bank-level market shares given the Alipay exposure IV, the Hangzhou distance IV, and both used simultaneously.

\section{FinTech Payment Creates Liquid Assets: City-Level Evidence}

In this section, we begin by testing the relevance of our IVs and investigate the relationship between FinTech payment and FinTech money market fund popularity through city-level first-stage regressions. Then we examine the aggregate impact on deposit flows into FinTech money market funds using citylevel penetration and Yu'ebao money market fund subscription data.

\subsection{First-Stage Results: Alipay Penetration and Distance to Hangzhou}

We first examine the relevance of our two instruments graphically. As shown in Panel A of Figure 5, the expansion of the Yu'ebao user base in December 2013 tightly correlated with the existing geographical patterns of Alipay users as of May 2013. We exploit this predetermined spatial variation as an instrument for the uptake of Yu'ebao, under the instrument relevance and exclusion restriction for which we argued 
earlier.

We run the following first-stage regressions:

$$
\begin{aligned}
& \log E_{c, 2013}^{Y E B}=\beta_{0}+\beta_{1} \log E_{c, 2013}^{A L I}+X_{c}^{\prime} \beta+\epsilon_{c} \\
& \log E_{c, 2013}^{Y E B}=\beta_{0}+\beta_{1} \log H Z \text { Distance }_{c, 2013}+X_{c}^{\prime} \beta+\epsilon_{c} \\
& \log E_{c, 2013}^{Y E B}=\beta_{0}+\beta_{1} \log E_{c, 2013}^{A L I}+\beta_{2} \log H Z \text { Distance }_{c, 2013}+X_{c}^{\prime} \beta+\epsilon_{c}
\end{aligned}
$$

Panel A of Table 2 summarizes the city-level first-stage regressions. Columns (1) and (2) present the results using pre-Yu'ebao Alipay penetration as the instrument for Yu'ebao penetration. We find that a one percent increase in log Alipay penetration leads to a significant 1.143 percent increase in Yu'ebao penetration in the univariate regression in Column (1), with a nearly identical estimate of 1.105 when we add city-level controls in Column (2). The R-squared values from these regressions are 0.950 and 0.958, respectively. As this analysis shows, the use of FinTech payment technology ex-ante strongly predicts adoption into using Yu'ebao.

Next, we use the geographical distance to Hangzhou, the headquarter city of Alipay and Yu'ebao (which is pre-determined), as a second instrument. Distance matters for the diffusion and marketing of FinTech products. Panel B of Figure 5 shows a negative correlation between geographical distance and Yu'ebao penetration. Table 2 Panel A shows formally that distance to Hangzhou is a statistically significant predictor of Yu'ebao penetration. These results are somewhat weaker than the Alipay instrument, but nevertheless the coefficients on log Hangzhou distance in Columns (3) and (4) are both negative and significant, as expected: A $1 \%$ greater distance from Hangzhou corresponds to a $-0.579 \%$ and $-0.352 \%$ lower Yu'ebao penetration for specifications with and without controls, respectively. Finally, the results are robust to including both IVs in the first-stage regressions, as shown in Columns (5) and (6). The coefficients on Alipay penetration and Hangzhou distance are significant and have the same signs as when used separately as instruments.

Before moving on, we remark that coefficients on $\ln ($ city_branchshare), the log value of each city's share in the national bank branch network, are negative. This result demonstrates the inclusiveness of FinTech banking: Yu'ebao gains more popularity in cities with fewer traditional bank branches, other things being equal. FinTech helps meet the demand for financial services not fully provided by tradi- 
tional brick-and-mortar bank branches.

\subsection{Deposit Flows and Yu'ebao}

Accroding to CHFS survey of Chinese households, ${ }^{16}$ between 2011 (two years before the Yu'ebao was launched) to 2015 (two years after Yu'ebao), bank deposits as a share of Chinese household savings declined from 58.0 percent to 45.8 percent. We estimate the role of Fintech in this pattern. In particular, we explore cross-city or cross-bank variations in Fintech user penetration and the instrumental variable approach described earlier to estimate how FinTech affects the funds deposited into Yu'ebao. This is important to examine separately because registering a Yu'ebao account does not necessarily lead to Yu'ebao purchases, and Yu'ebao purchases—particularly those made from bank cards—are what ultimately reflect depositors' preferences for Yu'ebao over bank deposits.

The first outcome variable we consider is flows into Yu'ebao from bank deposits, which we track at the city level within the first twelve months following the introduction of Yu'ebao. We also examine the total city-level Yu'ebao balance as of May 2014. In particular, we define for city $c$,

$$
\begin{aligned}
& \text { FundFlow } \text { C }_{c}=\text { Cumulative Yu'ebao flows from banks, June } 2013 \text { - May } 2014
\end{aligned}
$$

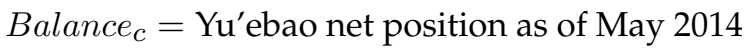

Panel A of Figure 6 shows that Yu'ebao user penetration predicts city-level fund flows into Yu'ebao from banks during the 12 months following Yu'ebao's introduction. Additionally, there is also a positive relationship between Yu'ebao user penetration and city-level Yu'ebao balance as of May 2014 (one year since the launch of Yu'ebao), as shown in Panel B of Figure 6.

Table 3 presents the city-level cross-sectional regressions results. We begin with specification (8), the city-level regression, using fund flows as the outcome variable. Column (1) shows the univariate baseline OLS results using the log value of the Yu'ebao penetration ratios as the regressor. This regression shows that a one percent increase in Yu'ebao penetration is associated with a 1.527 percent greater deposit flow into Yu'ebao from banks.

Column (2) includes a set of city characteristics as control variables to account for factors that affect both FinTech user penetration and future fund flows into Yu'ebao. They include a dummy for cities

\footnotetext{
${ }^{16}$ https://chfs.swufe.edu.cn/Upload/.pdf
} 
thare are provincial capitals, log GDP, log population, and the share of the city's bank branches in the national bank branch network (city_bankshare). We fix their values to the pre-Yu'ebao levels in 2012. Controlling for these city characteristics neither affects the sign nor the statistical significance of the coefficients, but does reduce the economic magnitude: in the regression with controls, the magnitude of the coefficient drops to 1.10 .

As for the effects of the other covariates, we find that cities with higher GDP or larger population experience a larger deposit outflow to Yu'ebao, but otherwise no significant difference for provincial capitals. Interestingly, cities with more traditional bank branches (represented by a larger share in the national bank branch network) exhibit a greater deposit outflow holding other observables constant. A possible interpretation is that cities with more bank branches had more severe financial repression before Yu'ebao since a larger fraction of funding would have been kept in regulated deposit accounts prior to Yu'ebao. As Yu'ebao is an important competitor to bank deposits, it is not surprisng that these cities experience larger fund outflows when Yu'ebao is launched.

A reverse causality concern applies to these OLS specifications. Hence, we utilize our two instrumental variables discussed earlier. We present the results for the Alipay exposure IV, the Hangzhou distance IV, and the (overidentified) combination of the two in Columns (3), (4), and (5), respectively. Reassuringly, these instruments yield qualitatively similar and statistically robust results that are similar to the baseline specifications. Finally, Table 3 Panel B replicates the preceding regressions using total Yu'ebao balances as of May 2014 in the place of cumulative flows as the left-hand side variable. This variable measures a similar quantity, and as expected the results in Panel B are quite similar to the preceding findings.

To summarize, greater Yu'ebao penetration in a city robustly leads to greater flows out of bank deposits and into Yu'ebao. This finding is true in both the OLS setting and the quasi-experimental setting using either pre-Yu'ebao Alipay penetration or distance from Hangzhou as instruments. The city-level analysis demonstrates the competitive relationship between Yu'ebao and bank deposits and highlights the importance of FinTech payment to the expansion of Yu'ebao's user base. In the next section, we examine deposits at the bank level and study the banks' response to FinTech competition. 


\section{FinTech Competition and Banks' Response}

We begin our bank-level analysis by examining how deposit growth changes by customer type and product type: household versus firm deposits and demand versus time deposits. This approach allows for a more detailed study of which products in particular are more affected by FinTech entry. Recall, Yu'ebao is the closes substitute for household (as opposed to firm) and demand (as opposed to time) deposits. Thus, we expect a stronger relationship between household demand deposit growth and Yu'ebao as compared to all other deposit segments. We additionally examine the differentiated impact on banks with different characteristics, such as bank size, bank branch share, and banks' reliance on deposits for funding.

We first examine the first stage results from our instruments. Mechanically, as the city locations of bank networks differ by banks, the FinTech exposure of banks is a linear combination of the city-level FinTech exposure, and likewise, the Hangzhou distance of a bank is the linear combination of citylevel distances from Hangzhou. Thus, we expect the relationship between Yu'ebao penetration and the two instruments for it to remain intact. Panel B of Table 2 confirms this with the bank-level first-stage regression results. Similar to the city-level results, the IVs are significant and robust. As with the citylevel regressions, banks with greater exposure to Alipay have significantly higher exposure to Yu'ebao as shown in Columns (1) and (2), where a 1\% greater Alipay exposure is associated with a $1.182 \%$ and $1.204 \%$ greater Yu'ebao exposure, respectively. Similarly, banks with a greater distance from Hangzhou have less exposure to Yu'ebao, as shown in Columns (3) and (4), where a 1\% lower distance to Hangzhou is associated with a $0.630 \%$ and $0.411 \%$ greater Yu'ebao exposure, respectively. The instruments are statistically significant and robust both when used alone and when used together, as shown in Columns (5) and (6).

\subsection{Bank Deposit Growth and FinTech Competition in Retail Funding}

Yu'ebao is the best substitute particularly for household demand deposits; that is, it offers immediate liquidity though a platform oriented towards retail users. Therefore, the launch of Yu'ebao should mainly affect the growth rate of personal/household deposits rather than that of corporate/firm deposits and have a larger impact on retail demand deposits than retail time deposits.

Table 4 shows results consistent with this hypothesis obtained by regressing banks' deposit growth 
rates, broken out by household and firm deposits, between 2012-2014 on their exposure to FinTech competition. Columns (1)-(4) show the results for household deposits; Columns (5)-(8) show the results for firm deposits. We find the effects are significantly negative for bank-level household deposit growth but insignificant for bank-level firm deposit growth, after the initial level and mean reversion channel are controlled. A 1\% increase in Yu' ebao exposure leads to a 7-9\% decrease in household deposit growth. The effect is economically large relative to, e.g., own-price elasticities of demands estimated in other contexts, which tend to be around $1 .{ }^{17}$ The results utilizing the instrumental variables are reported in (2)-(4) and (6)-(8), and are strong and robust. Breaking down the categories of deposits further, Table 5 shows Yu'ebao competition depresses household demand deposit growth, Columns (1)-(4), but not household time deposit growth, Columns (5)-(8).

The preceding regression uses deposit growth between 2012 and 2014. To examine the longer-run impact of FinTech competition on deposit growth, we expand the horizon in the baseline regression. Table 6 presents the regression results on deposit growth during 2012-2015 and during 2012-2016, shown in Columns (1)-(16), respectively. Similar to our baseline results, the coefficients are significantly negative on household deposits and insignificant on corporate deposits. Thus, the competitive effect of Yu'ebao on bank deposits is long-lasting.

Summarizing, the negative effect of Yu'ebao on deposit growth is concentrated in the segment for which it offers the best substitute, household demand deposits. These results support the FinTech competition channel: (1) FinTech creates a close substitute to bank demand deposits since $T+0$ fast redemption is a major selling point of the FinTech product; (2) the competition between Yu'ebao and bank deposits is strongest for retail depositors, rather than the wholesale or institutional clientele, since the low investment threshold and no cash-out fee features of Yu'ebao appeal mainly to retail investors.

So far, an unaddressed identification concern is that banks with higher exposure to FinTech competition are systematically different from those with lower expose in terms of deposit growth. In other words, deposit growth may be on a different pre-trend for the most exposed versus leased exposed banks. To rule out this possibility, we run a placebo test of the preceding regressions by changing the time period of the outcome variable from 2012-2014 to 2010-2012. A significant result here would indicate important differences in deposit growth that are not plausibly related to the Yu'ebao competition mechanisms we have in mind. Table 7 shows the regression results of this placebo test. All coefficients

\footnotetext{
${ }^{17}$ See, e.g., Ho and Ishii (2011)
} 
before the FinTech exposure (including the IV results) are insignificant, which supports our argument that deposit-like FinTech products' introduction lead to a decline in banks' deposit growth, rather than a merely fortuitous correlation with some unobserved driver of deposit growth.

Furthermore, the null result in this placebo tests shows that the effect is not driven solely by the entry of a new FinTech payments system. In other words, it is not simply the fact that banks lose business to a competing payment technology that causes bank deposits to flow out of the banking system because the Alipay has existed for about a decade by then. Rather, exposure to FinTech matters for deposits only around the introduction of Yu'ebao, which bundles payments with more competitive, unrepressed interest rates.

\subsection{Banks Introducing Yu'ebao Competitors}

The previous section has highlighted significant deposit outflows-particularly among household demand deposits, which are close substitutes for Yu'ebao-from the banks most exposed to Yu'ebao. In this section we look for direct evidence of their response. In particular, we ask whether the exposed banks begin to offer competing bao products - those with a market interest rate and $\mathrm{T}+0$ no-cost redemption.

While Yu'ebao was the first of its kind, banks had the capacity to respond by introducing their own bao products. Using our hand-collected dataset of bao products, we define a dummy for whether bank $b$ offers a competing Yu'ebao-like money market fund (MMF) by the end of 2017, roughly four-and-a-half years after Yu'ebao's introduction, around the time that Yu'ebao crossed the one-trillion yuan assetsunder-management mark. We then test whether banks with greater Yu'ebao exposure were more likely to introduce these products than other banks, regressing the dummy variable $b a o_{b}$ on Yu'ebao exposure and bank-level controls.

We find strong affirmative evidence through the linear regressions, as summarized in Panel A of Table 8. Column (1) shows the baseline OLS result with control variables. A one percent increase in Yu'ebao exposure is associated with a roughly $12 \%$ greater likelihood of the bank introducing a bao product within the time frame. Columns (2)-(4) instrument Yu'ebao exposure with Alipay penetration, Hangzhou distance, and both, respectively. Across these instrumental variable specifications, we find robust evidence that exposure to Yu'ebao competition causes banks to introducing competing bao prod- 
ucts. The results are robust, and the magnitudes of the coefficients are similar across the specifications. In other words, banks facing more Yu'ebao competition tend to respond by rolling out their own products with a market interest rate. Their deposit customers can now have access to market interest rates on their savings even if they do not move their money to Yu'ebao.

The control variables in these regressions provide additional insight into which banks introduced bao products beyond their differential exposure to Yu'ebao. Other things being equal, larger banks, or those with a greater reliance on deposit funding are more likely to launch bao-type products. Interestingly, banks with more branches are less likely to keep up with the FinTech competition, although the strength of this association is weak. Several potential explanations exist. One is the replacement cost: banks with more brick-and-mortar bank branches may find it more expensive to introduce innovations that would attract fund flows away from bank deposits. Another explanation is clientele differentiation: banks with more brick-and-mortar branches may have deposit customers of the type (e.g., older people) that differs from the target users of FinTech products.

As a robustness check, we run the preceding analysis with a hazard model, which allows us to take advantage of the time-dependent structure of the starting time of the bao products. The hazard specification uses the (potentially truncated) time to introduce bao products as the outcome variable, and we follow a standard hazard specification modeling the hazard rate $\lambda(t ; X)$ as

$$
\lambda(t ; X)=\lambda_{0}(t) \exp \left(\beta_{0}+\beta_{1} \log E_{b, 2013}^{Y E B}+X_{b}^{\prime} \beta\right)
$$

where $\log E_{b, 2013}^{Y E B}$ is the bank's direct or instrumented exposure to Yu'ebao and $X_{b}^{\prime}$ represents the banklevel controls. As shown in Panel B of Table 8, the coefficients from the hazard model strongly confirm the earlier linear probability models' findings, and as before, the IV results are consistent with the baseline. In other words, the likelihood that a bank rolls out a bao product rises with the extent of the exposure to Yu'ebao competition. The FinTech competition helps to end the financial repression for bank customers. In addition, banks with a larger size and fewer brick-and-mortar branches are more likely to launch bao products. 


\subsection{Comparison: WMPs that are not Deposit Substitutes}

Finally, for comparison, we examine wealth-management products (WMPs) issued by banks that require a high minimum-investment level typically in excess of 50,000 RMB. These products target relatively wealthy customers. These products paid an interest rate close to the market rate even before Yu'ebao but their high minimum-investment requirement without a $\mathrm{T}+0$ redemption feature makes it not accessible to most ordinary households. If the channel for our findings is through the competitive pressures on demand deposits held by almost all households, we may find little effect of the Yu'ebao exposure on the issuance and yields of those WMPs.

This is confirmed in Table 9. Contrary to their response in rolling out bao products, banks do not appear to change WMP issuance and yields according to their exposure to FinTech. This result is consistent with our main idea that it is the FinTech competition that induces banks to innovate and launch bao products, which benefits households with higher market interest rates and facilitates interest rate liberalization reform in China, and serves as a placebo test to rule out the idea that more exposed banks are the types of banks to issue products generally.

\section{Impact of FinTech on Traditional Banks' Performance}

In this section, we analyze the impact of the entry of FinTech competition on traditional bank profitability and risk-taking activities. We examine the impact on bank balance sheet measures of profitability and costs, including net interest margin, interest income, net profits, cost-to-income ratio, bank risky asset ratio, bad loan ratio, and bank loan structure.

\subsection{Bank Interest Rate Spread and Profitability}

The previous analysis suggests that banks and cities most exposed to Yu'ebao see reduced deposit growth-particularly among the products for which Yu'ebao is the closest substitute, household demand deposits. This presents a potential policy concern, in that these deposit outflows may negatively impact bank profitability and financial stability. To assess the economic significance of this effect, we use the bank-level OLS and IV specifications to examine changes in bank financials from 2012 to $2014 .^{18}$.

\footnotetext{
${ }^{18}$ There was a regulatory change in the reporting standard of commercial bank balance sheets in 2013. However, to the extent that the impact of the reporting standard change is not proportional to banks' exposure to the Yu'ebao shock, our regression results
} 
We examine changes in net interest margin, profits, revenues, and costs. The empirical strategy exactly mirrors that used before for the bank-level analysis, and so we move directly to the results.

While a large outflow from the banking system is a potential cause for concern among banking regulators, we find that, surprisingly, cross-sectional differences in outflows had little differential impact on bank balance sheets. As shown in Table 10, the most exposed banks saw no greater changes in performance measured as net interest margins (NIMs), suggesting that the deposit outflows did not significantly hamper banks' ability to engage in traditional spread lending. Most of the variation in NIMs is absorbed by the initial values, i.e., the starting value in 2012, suggesting significant mean reversion in these measures, but little cross-sectional differences related to exposure to Yu'ebao. While we see mixed results when examining profits from core and interest businesses, as shown in Tables 11 and 12, these results are not robust: Core profits decline modestly across most specifications, but we cannot attribute these changes specifically to decreases in core revenues or increases in core expenditures. Moreover, we see no impact on interest-based businesses.

\subsection{Bank Lending and Risk-taking Activities}

Finally, we examine whether the most exposed banks differentially increased the risk of their assets as measured as bad loan ratios ${ }^{19}$ or the share of risky assets in total assets ${ }^{20}$ As shown in Columns (1)-(4) of Table 13, banks with greater exposure to Yu'ebao do not experience a significant increase in their bad loan ratios from 2012 (the year before Yu'ebao) to 2014 (one and half year after Yu'ebao). Similarly, there is no evidence that those banks more exposed to Yu'ebao competition raise their share of risky loans in total assets. If anything, there is some evidence that they might have lowered their exposure to risky loans. Thus, the Yu'ebao competition does not appear to induce banks to engage in more on-balancesheet risk-taking activities.

are not affected by this change.

${ }^{19}$ Loans are categorized into five types in descending order of quality: (1) normal (zhengchang), (2) meriting attention (guanzhu), (3) subprime (ciji), (4) suspicious (keyi), (5) loss (sunshi). The last three categories are considered bad loans by regulators. The bad loan ratio (bulianglv) is the sum of the last three categories as a share of the total loan value.

${ }^{20}$ The risky asset ratio is risky assets (with risky weights determined by the regulatory authority based on the Basel Accords) divided by the total assets of a bank. 


\section{Discussion and Conclusion}

We examined the equilibrium effect of a new FinTech entrant that competes directly with bank household demand deposits. Bank deposits in China were subject to financial repression, constraining interest rates far below the apparent laissez-fair level. Interest rate regulation of such type is common among developing countries and is known as "financial repression" in the development finance literature. The entry of Yu'ebao, China's first FinTech MMF that offers T+0 liquidity and transaction services, while not being subject to interest rate caps, has the effect of siphoning deposits out of the traditional banking system. In the cross-sectional analysis, cities and banks with the greatest exposure to Yu'ebao faced most significant deposit outflows. These findings are robust to several instrumental variable approaches that address potential endogeneity problems.

The exit of bank deposits from the traditional banking system is potentially a concern for regulators. One possibility is that, facing greater deposit competition, banks become less profitable and the stability of the financial system is undermined. However, we find that the banks most exposed to Yu'ebao did not see compressed net interest margins or reduced profitability. Rather, we find that the most exposed banks responded by launching their own competing $\mathrm{T}+0$ money market fund products, further undermining financial repression.

We flag several limitations in our approach. First the analysis is cross-sectional, and therefore it is unable to cleanly identify aggregate, time-series effects. However, given the robustly insignificant results on bank profitability in the face of significant cross-sectional heterogeneity in the treatment and deposit outflows, it is unlikely that aggregate effects on bank profitability could be large.

Second, our paper focuses on Yu'ebao in its early stages without analyzing the longer-term impact of FinTech competition on traditional banks. This is particularly relevant for outcomes around bank risk taking. While we found no effects on loan riskiness or ex-post performance it is possible that these effects may take longer to materialize than we would be able to detect in our window of analysis. In April 2017, Yu'ebao became the largest money-market fund in the world, with assets under management totaling \$165.5 billion. This surpassed even JP Morgan Chase's US Government market fund with AUM of $\$ 150$ billion. This unprecedented size could bring significant liquidity and systematic risks that have yet to materialize. With these concerns, regulators in China have begun to enhance regulations on money market funds, for example, by restricting the use of $T+0$ redemption and limiting the size of 
any single money market fund. It is possible that the impact of FinTech products in their early stages may be different from the impact in their mature stages. Examining the long-term impact of FinTech competition is a meaningful and fruitful path for future research.

Our results highlight the potential of FinTech to be a bottom-up liberalizing force in developing economies that are potentially hampered by a history of financial repression. The findings highlight both the direct effect of Yu'ebao, a deposit-like product that was not subject to interest rate caps, and the indirect effect of banks introducing their own competing products due to competitive pressure, on passing through more market rates to ordinary households. Our results also suggest that innovation and efficiency improvement by exposed lenders can help them avoid suffering large losses relative to banks who were less exposed but did not introduce their own competing products.

Taking a more global view, our research bears important similarities around the phasing out of Regulation Q in the United States. In the US case, thrifts and savings and loans were exempt from Regulation $\mathrm{Q}$ and though small individually, had a relatively large aggregate market share in other consumer finance products like mortgages. These smaller, exempt players played a similar role to Yu'ebao in our paper's context, even though they still existed within the existing financial sector. In the Chinese case, on the other hand, owing to the high concentration of large banks, the within-sector competitive impetus for liberalization was limited. Rather, the competition came from outside of the traditional financial sector, and tech companies played a key role.

Finally, our results highlight important synergies between FinTech savings platforms, mobile payment, and e-commerce. E-commerce has historically fallen outside the purview of traditional banking services but allowed Yu'ebao to rapidly gain market share among consumers already on the Alipay platform. As digital payment and other non-traditional financial services grow worldwide, the Chinese experience-where the rise of FinTech did not destabilize the traditional banking system, but rather spurred competitive innovation-holds important lessons for understanding the efficiency and financial stability consequences of FinTech innovations in other countries. 


\section{References}

Acharya, V., J. Qian, Y. Su, and Z. Yang (2020). In the shadow of banks: Wealth management products and issuing banks risk in china. NYU Stern School of Business.

Berg, T., V. Burg, A. Gombović, and M. Puri (2020). On the rise of fintechs: Credit scoring using digital footprints. The Review of Financial Studies 33(7), 2845-2897.

Boot, A. W. (2017). The future of banking: From scale \& scope economies to fintech. European Economy.

Brunnermeier, M. K., M. Sockin, and W. Xiong (2017). China's gradualistic economic approach and financial markets. American Economic Review.

Brunnermeier, M. K., M. Sockin, and W. Xiong (2020). China's model of managing the financial system. Working Paper, National Bureau of Economic Research.

Buchak, G., G. Matvos, T. Piskorski, and A. Seru (2018a). Beyond the balance sheet model of banking: Implications for bank regulation and monetary policy. Working Paper, National Bureau of Economic Research.

Buchak, G., G. Matvos, T. Piskorski, and A. Seru (2018b). Fintech, regulatory arbitrage, and the rise of shadow banks. Journal of Financial Economics.

Chen, K., J. Ren, and T. Zha (2018). The nexus of monetary policy and shadow banking in china. American Economic Review.

Claessens, S., J. Frost, G. Turner, and F. Zhu (2018). Fintech credit markets around the world: size, drivers and policy issues. BIS Quarterly Review September.

D'Acunto, F., N. Prabhala, and A. G. Rossi (2019). The Promises and Pitfalls of Robo-Advising. The Review of Financial Studies.

Fuster, A., M. Plosser, P. Schnabl, and J. Vickery (2019). The role of technology in mortgage lending. The Review of Financial Studies 32(5), 1854-1899.

Gennaioli, N., A. Shleifer, and R. W. Vishny (2013). A model of shadow banking. The Journal of Finance.

Goldstein, I., W. Jiang, and G. A. Karolyi (2019). To fintech and beyond. The Review of Financial Studies. 
Ho, K. and J. Ishii (2011). Location and competition in retail banking. International Journal of Industrial Organization 29(5), 537-546.

Hong, C. Y., X. Lu, and J. Pan (2019). FinTech Platforms and Mutual Fund Distribution. Working Paper, National Bureau of Economic Research.

Hong, C. Y., X. Lu, and J. Pan (2020). FinTech Adoption and Household Risk-Taking. Working Paper, National Bureau of Economic Research.

Jack, W. and T. Suri (2014). Risk sharing and transactions costs: Evidence from kenya's mobile money revolution. American Economic Review.

Jiang, E., G. Matvos, T. Piskorski, and A. Seru (2020). Banking without deposits: Evidence from shadow bank call reports. Technical report, National Bureau of Economic Research.

Ma, Y., K. Xiao, and Y. Zeng (2020). Mutual fund liquidity transformation and reverse flight to liquidity.

McKinnon, R. et al. (1973). Money and capital in economic development.

Moreira, A. and A. Savov (2017). The macroeconomics of shadow banking. The Journal of Finance.

Navaretti, G. B., G. Calzolari, J. M. Mansilla-Fernandez, and A. F. Pozzolo (2018). Fintech and banking. friends or foes?

Parlour, C. A., U. Rajan, and H. Zhu (2020). When fintech competes for payment flows.

Philippon, T. (2016). The fintech opportunity. Working Paper, National Bureau of Economic Research.

Shaw, E. S. (1973). Financial deepening in economic development.

Song, Z. and W. Xiong (2018). Risks in china's financial system. Annual review of financial economics.

Tang, H. (2019). Peer-to-peer lenders versus banks: substitutes or complements? The Review of Financial Studies.

Thakor, A. V. (2020). Fintech and banking: What do we know? Journal of Financial Intermediation.

Vallee, B. and Y. Zeng (2019). Marketplace lending: A new banking paradigm? The Review of Financial Studies. 
Xiao, K. (2020). Monetary transmission through shadow banks. The Review of Financial Studies.

Xiong, W. (2018). The mandarin model of growth. Working Paper, National Bureau of Economic Research.

Zhang, A. T. (2021). Estimation of high-dimensional dynamic games: Fintech lenders and bank branch closures. 


\section{List of Variables}

\begin{tabular}{|c|c|}
\hline & A. City-level variables \\
\hline \multicolumn{2}{|l|}{ Dependent variables } \\
\hline fundflow & $\begin{array}{l}\text { Purchase fund flows from bank accounts to Yu'ebao, city level cumulative aggregate as of } \\
\text { May 2014. Ant Group. }\end{array}$ \\
\hline balance & City-levek Yu'ebao net position as of May 2014. Ant Group. \\
\hline \multicolumn{2}{|c|}{ Key explanatory variables } \\
\hline penetration_YEB & $\begin{array}{l}\text { A penetration index based on active mobile-end Yu'ebao users divided by local population, } \\
\text { December } 2013 \text { value. Ant Group. }\end{array}$ \\
\hline penetration_Alipay & $\begin{array}{l}\text { A penetration index based on active mobile-end Alipay users divided by local population, } \\
\text { May } 2013 \text { value. Ant Group. }\end{array}$ \\
\hline HZdistance & $\begin{array}{l}\text { A city's great-circle distance to Hangzhou city, Ali's headquarter. National Bureau for } \\
\text { Geographics, authors' calculation. }\end{array}$ \\
\hline \multicolumn{2}{|l|}{ Control variables } \\
\hline provincial_capital & $\begin{array}{l}\text { An indicator which equals one if a city is a provincial capital city and zero otherwise. Min- } \\
\text { istry of Civil Affairs, authors' calculation. }\end{array}$ \\
\hline branchshare_city & $\begin{array}{l}\text { A city's share in the national bank branch network; i.e., the number of bank branches in a } \\
\text { city divided by total bank branches nationwide. CBIRC, authors' calculation. }\end{array}$ \\
\hline gdp & City-level GDP, 2012 year-end value. WIND. \\
\hline population & City-level population, 2012 year-end value. WIND. \\
\hline grgdppc & $\begin{array}{l}\text { Average annual growth rate of a city's GDP per capita between 2012-2014. WIND, au- } \\
\text { thors' calculation. }\end{array}$ \\
\hline
\end{tabular}




\section{B. Bank-level variables}

\begin{tabular}{ll}
\hline Dependent variables & \\
\hline grdeposit & Bank level average annual growth rate of deposits between 2012-2014. Adding_hh, _firm, \\
& _demand, and_time after it means subcategories: household deposits, firm deposits, de- \\
& mand deposits, and time deposits, respectively. RESSET, authors' calculation. \\
& Indicator of whether a bank has launched bao-type products by December 2017 (=1 if yes \\
& and $=0$ otherwise). Authors' calculation. \\
\hline
\end{tabular}

Key explanatory variables

exposureYEB A bank's exposure to Yu'ebao using branch-weighted sum of city-level Yu'ebao penetration, December 2013 value. Ant Group, authors' calculation.

exposureAlipay A bank's exposure to Alipay using branch-weighted sum of city-level Alipay penetration, May 2013 value. Ant Group, authors' calculation.

bank_lnHZdistance A bank's branch-weighted sum of city-level distance to Hangzhou city, May 2013 value. Ant Group, authors' calculation.

\begin{tabular}{ll}
\hline Control variables & \\
\hline bank_deposit & The year-end deposits of a bank, 2012 value. Adding_hh,_firm,_demand, and_time \\
& after it means subcategories: household deposits, firm deposits, demand deposits, and time \\
& deposits, respectively. RESSET. \\
& The number of a bank's branches divided by total bank branches nationwide, May 2013 \\
branchshare_bank & value. CBIRC, authors' calculation. \\
size & Bank-level size proxied by total assets, 2012 value. RESSET. \\
bank_lngdppc & A bank's branch-weighted sum of lngdppc, 2012 value. WIND, authors' calculation. \\
bank_grgdppc & A bank's branch-weighted sum of gr_gdppc_1214. WIND, authors' calculation. \\
NIM & Net interest margin, 2012 value. A delta_prefix means the change between 2012-2014. \\
& RESSET. \\
NIS & Net interest spread, 2012 value. RESSET. \\
ratio_badloans & Non-performing loan ratio, 2012 value. RESSET. \\
ratio_riskyassets & Risky assets divided by total assets, 2012 value. RESSET. \\
\hline \hline
\end{tabular}




\section{Figure 1: DUAL-Track INTEREST RATES UNDER CEILINg Regulation}

Note: This figure shows the regulated interest rates of bank deposits and the market interest rates in the money market fund (MMF) industry in China during 2010-2018. The red solid line represents the 7-day annualized yield of Yu'ebao, the first FinTech MMF, while the blue dashed line refers to the 3-month Shanghai Inter-bank Offered Rates (SHIBOR). The grey dash-dot line is the maximum interest rate banks are allowed to offer on 3-month time deposits, while the black solid line is the interest rate cap on demand deposits (both were lifted in October 2015). The grey dashed vertical line marks the launching month of Yu'ebao (June 2013).

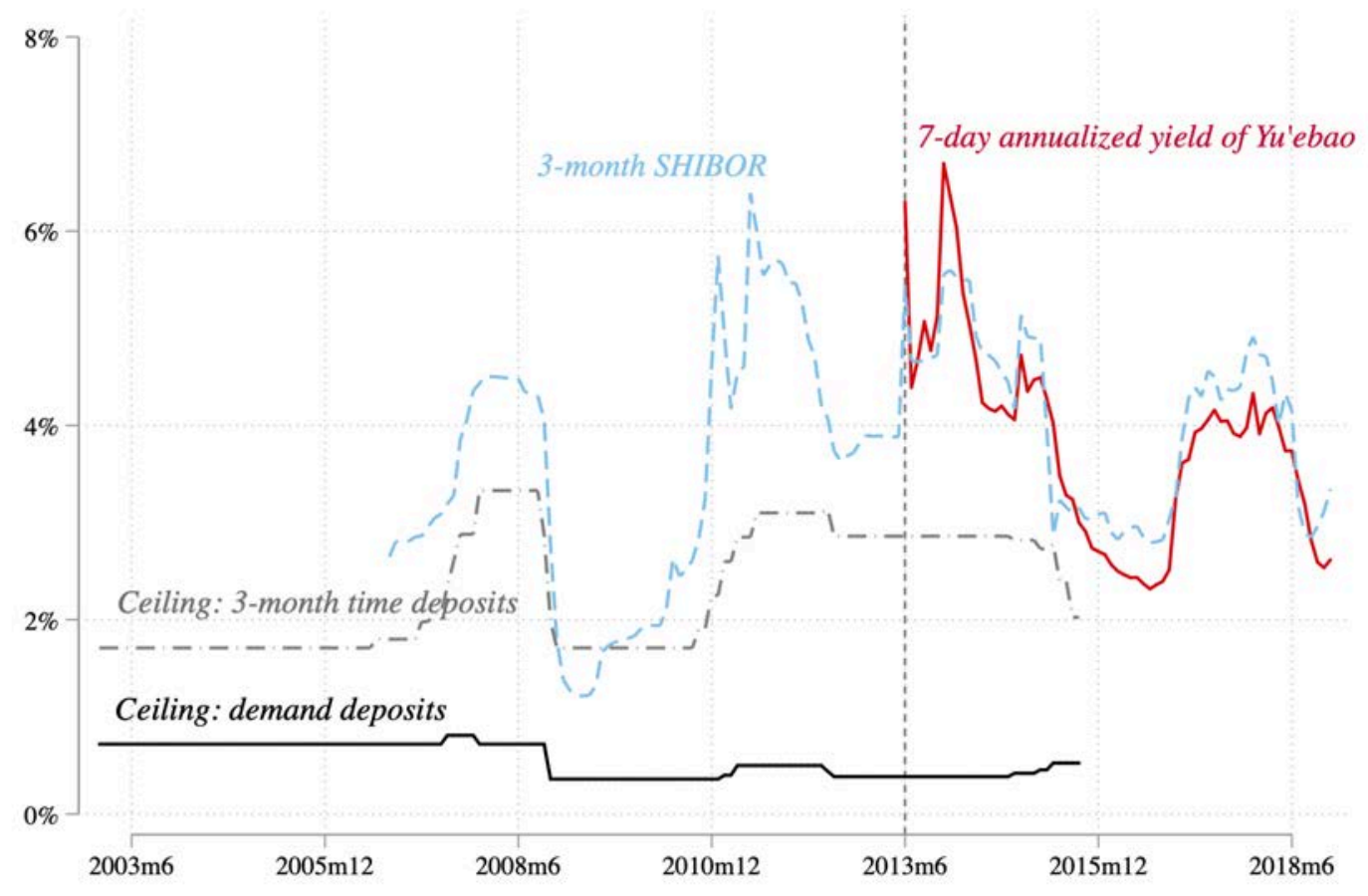




\section{Figure 2: HeAVy RELIANCE ON Deposit FUNDING IN THE BANKING INDUSTRY}

Note: This figure shows the reliance on deposit funding in the banking industry. The horinzontal axis plots the deposit-to-interest-bearing-liabilities (depositI BL) ratios as of December 2012. The vertical axis is bank market share as of May 2013. Red diamonds are the large state-owned banks, blue triangles are joint-stock banks, circles are city commercial banks, and triangles are rural community banks. The names of the six state-owned banks, which together make up $61.83 \%$ of bank branches, are labeled alongside the corresponding diamonds.

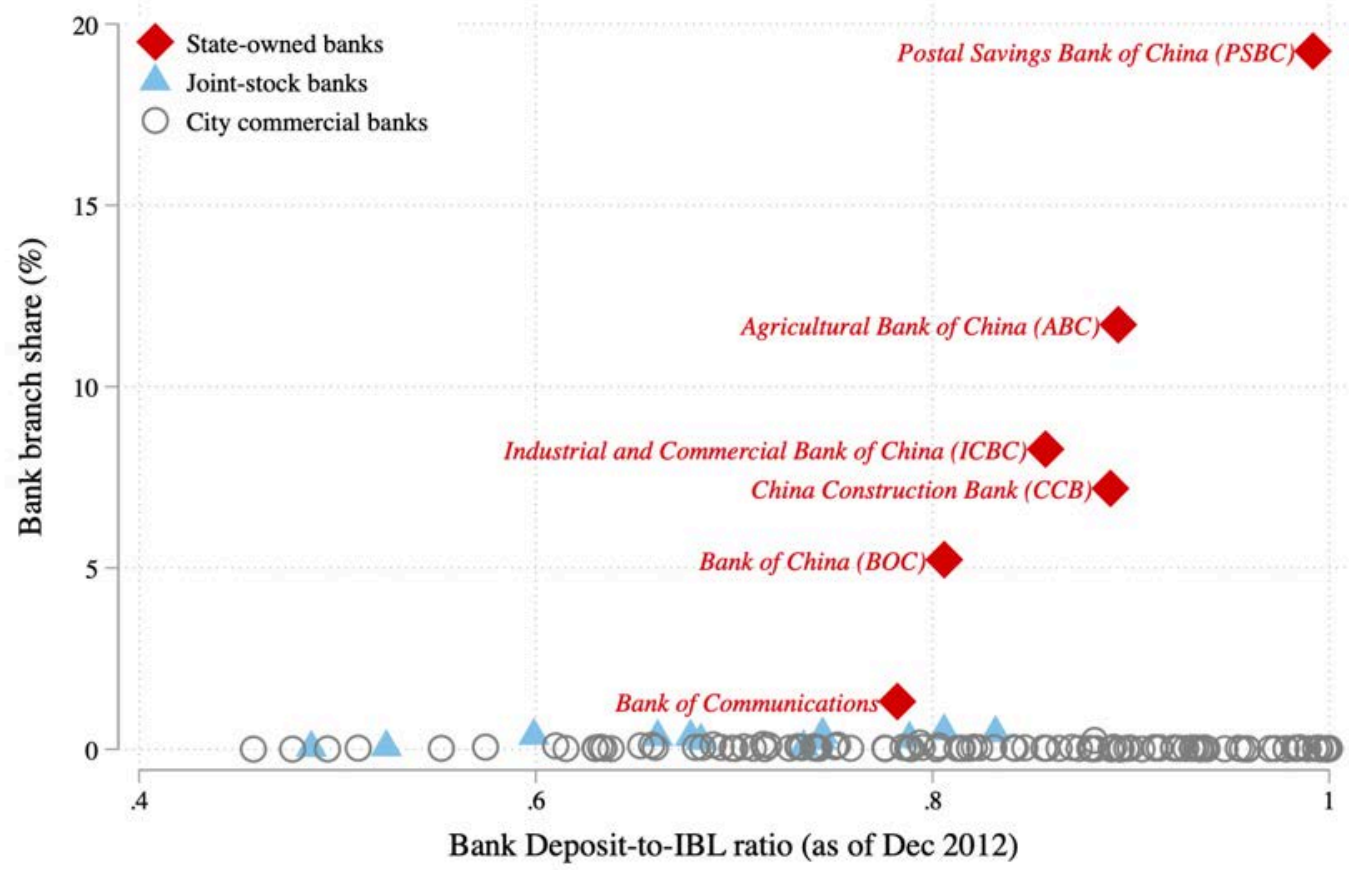




\section{Figure 3: When FinTeCh ENTERS INTO THE MMF IndUSTRY}

Note: Panel A of this figure shows the absolute and relative size (compared to bank deposits) of the money-market fund (MMF) industry in China since 2003. The red bars show the absolute size (left axis), while the blue line depicts the relative size (right axis). The gray dashed vertical line represents the launching month of Yu'ebao (June 2013). Panel B and C show the structural change in the MMF industry around the time of Yu'ebao's introduction, indicated by the dashed vertical gray line. Panel B shows the size of MMFs with $T+0$ fast redemption features distributed by Alipay, commercial banks, and other institutions (such as broker-dealers). Panel C shows the number of $T+0$ MMFs distributed by banks (red, left axis) and the number of unique banks distributing $T+0$ MMFs (blue, right axis).

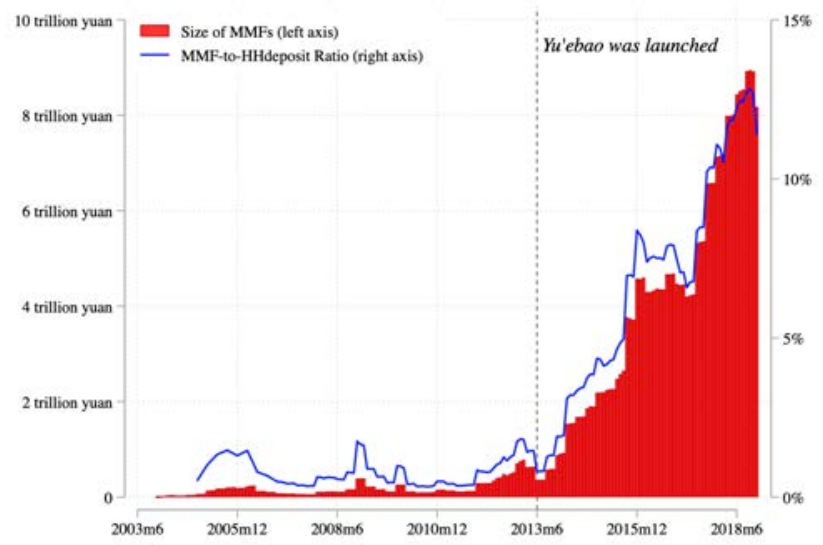

(A) MMF INDUSTRY COMPARED TO BANK DEPOSITS
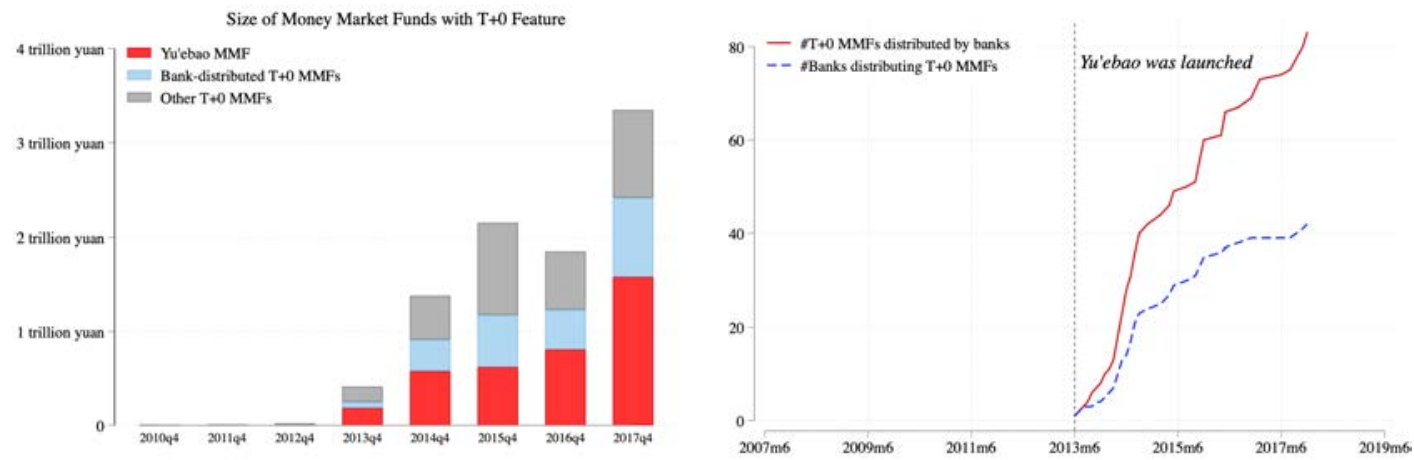

(в) Size OF T+0 MMFs distributed by Alipay, BANKS, AND OTHERS

(C) NUMBER OF BANK-DisTRIBUTED T+0 MMFS 


\section{Figure 4: FinTech Penetration across Cities}

Note: The figure plots city-level FinTech penetration ratios, defined as active mobile-end FinTech users divided by local population, in a gradient map. The upper panel A shows the penetration ratios of Yu'ebao in December 2013, six months since its introduction, while the lower panel shows the penetration ratios of Alipay in May 2013, one month prior to the introduction of Yu'ebao.

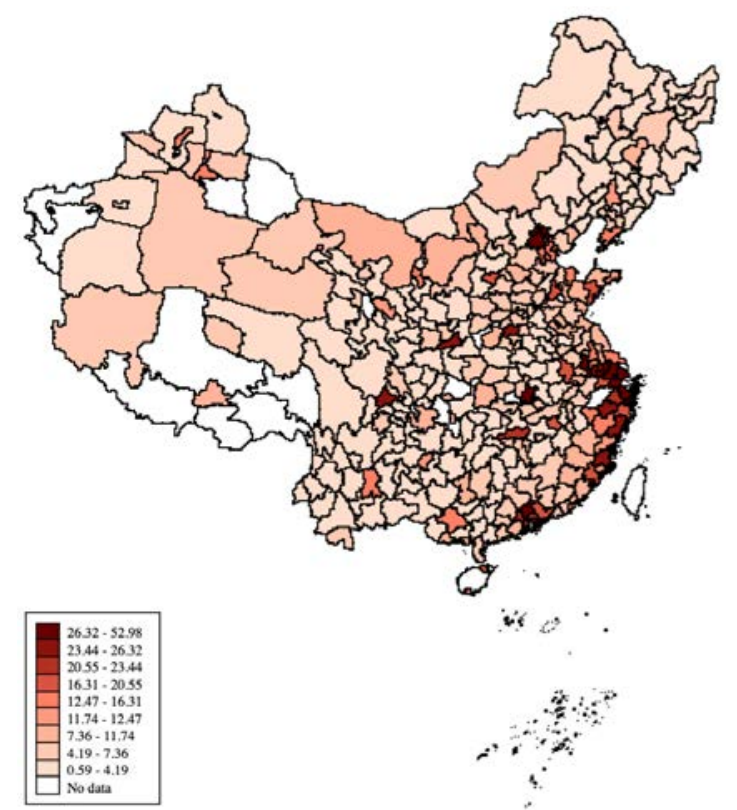

(a) FinTech MMf (Yu’ebao) User Penetration Ratio, Dec 2013

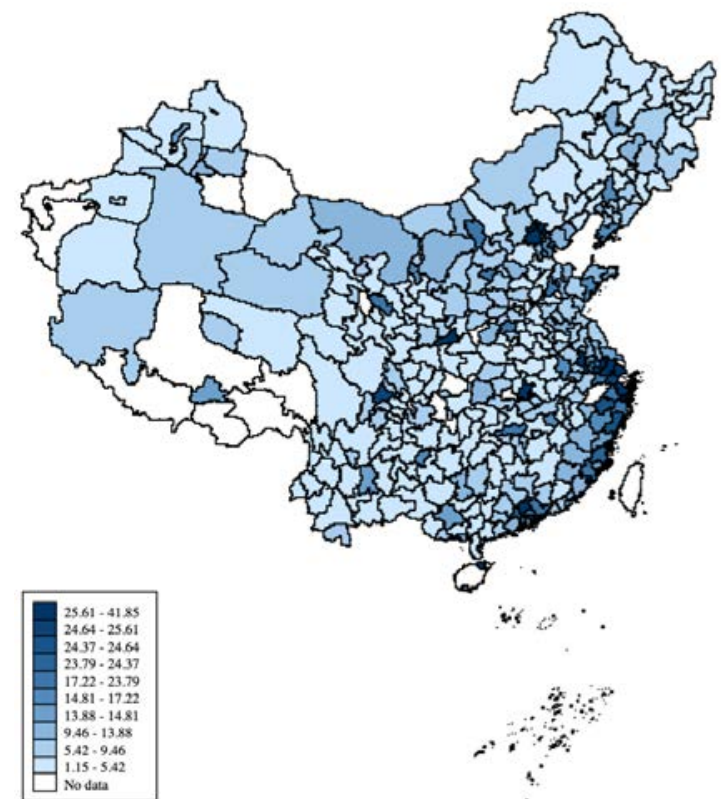

(B) FinTech Payment (Alipay) User Penetration Ratio, May 2013 


\section{Figure 5: City-LeVel First Stage}

Note: This figure demonstrate relationships between key FinTech penetrations and geographical distances. Panel A plots the relationship between city-level Yu'ebao (YEB) penetration ratios (log value as of December 2013, y-axis) and Alipay penetration ratios (log value as of May 2013, x-axis). Panel B shows the correlation between city-level Yu'ebao (YEB) penetration ratios (log value as of December 2013, y-axis) and each city's great-circle distance (log value) to Hangzhou city, the headquarter of Alipay and Yu'ebao (May 2013 value, x-axis). We distinguish between provincial capitals (plotted as diamonds) and non-provincial capital cities (plotted as circles). The fitted line is accompanied with a $90 \%$ confidence interval, plotted as the grey area.

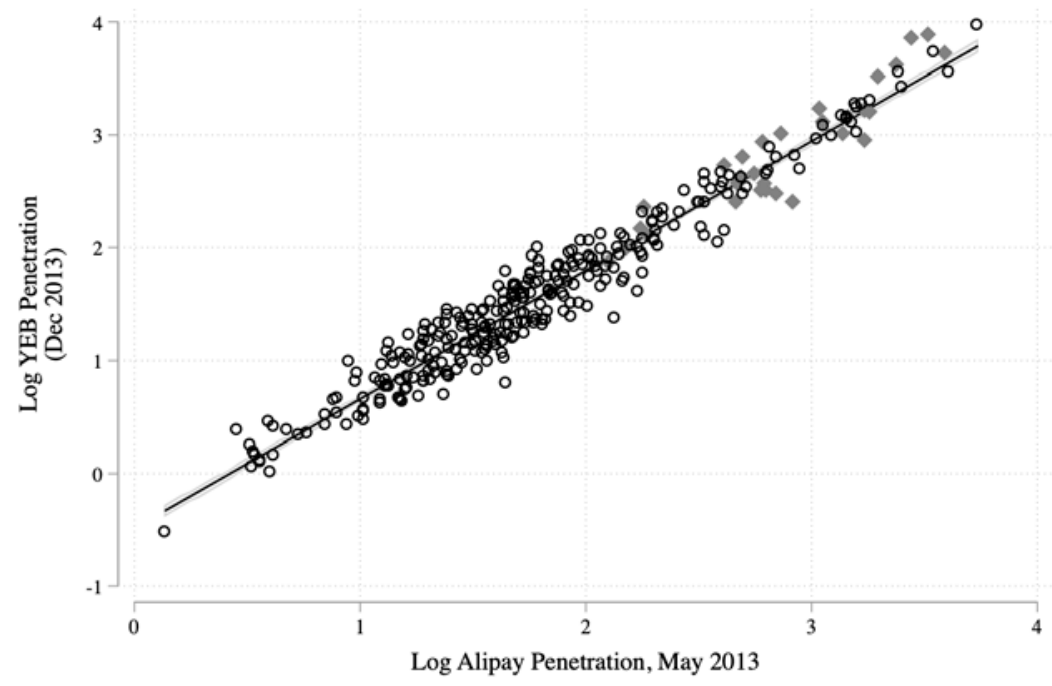

(a) Yu’ebao User Penetration Ratio (Dec 2013) and Alipay User Penetration Ratio (May 2013)

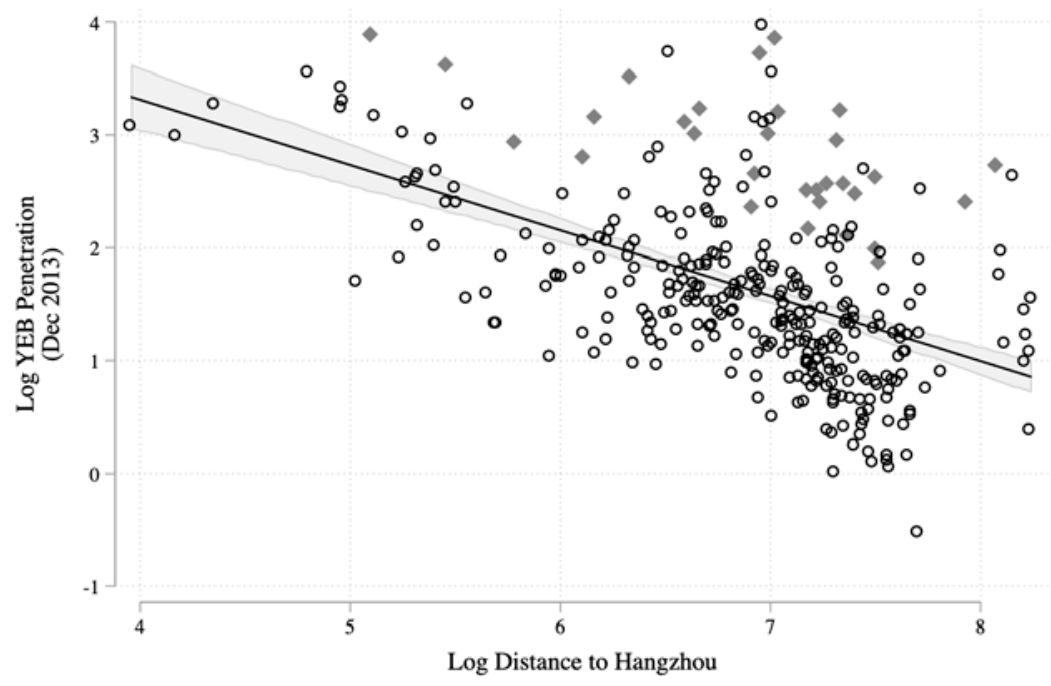

(B) Yu’ebao User Penetration Ratio (Dec 2013) and hangzhou Distance 


\section{Figure 6: City-level FinTech User Penetration and Deposit Outflows Per Capita}

Note: This figure plots the relationship between Yu'ebao user penetration and Yu'ebao MMF holdings. Panel (A) shows the relationship between Yu'ebao user penetration and city-level deposit funds int Yu'ebao. Panel (B) shows the relationship between Yu'ebao user penetration and city-level Yu'ebao balance as of May 2014 (one year since the launch of Yu'ebao). The solid line shows the best-fit regression with the gray region showing the confidence interval.

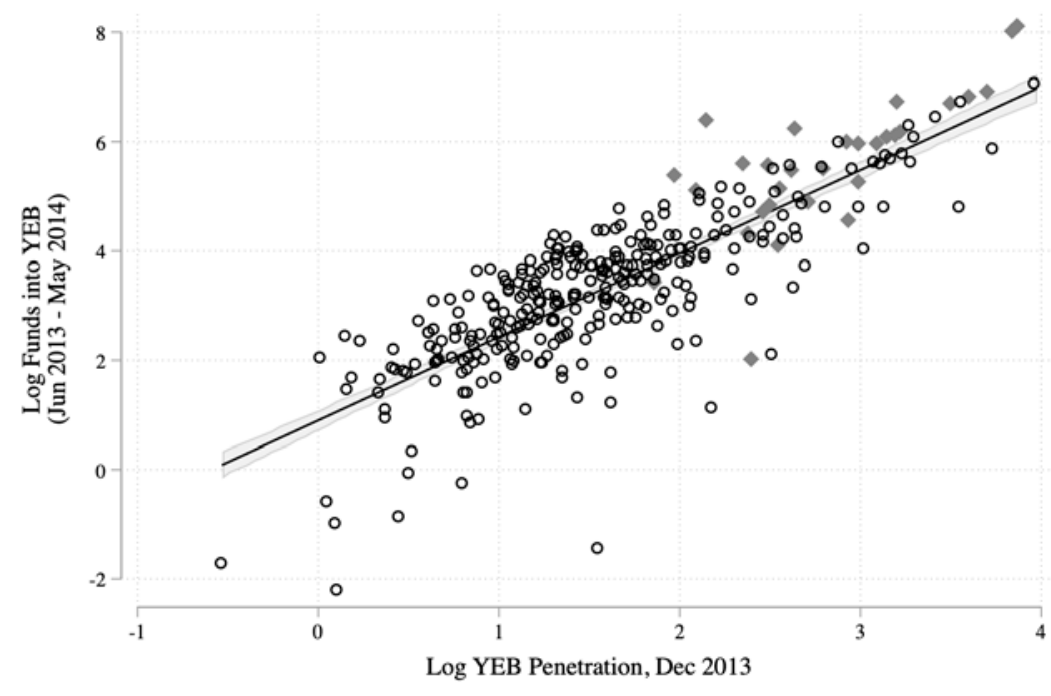

(a) User Penetration and City-level Funds into Yu'ebao MMF

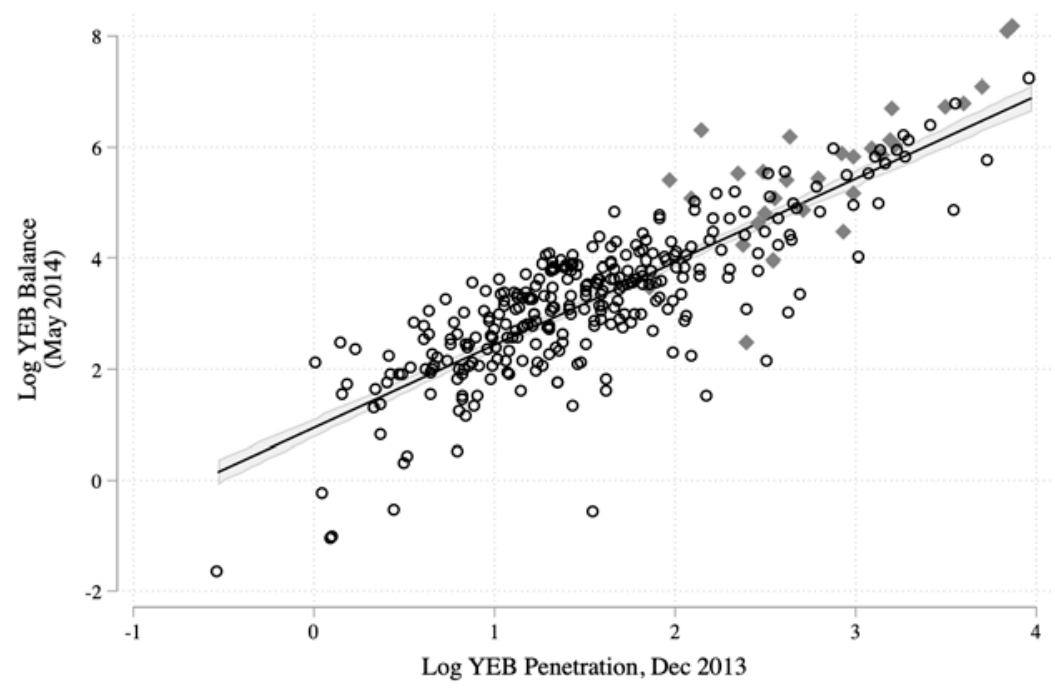

(в) User Penetration and City-level Yu'ebao MMF Balance 


\section{TABle 1: Summary STATistics}

Note: This table shows the summary statistics of the city-level and bank-level cross-section data. We exclude cities with extreme low or high values of distance to Hangzhou city, including Hangzhou city itself, Kizilsu Kyrgyz Autonomous Prefecture in Xinjiang Uyghur Autonomous Region, and Kashgar Prefecture in Tibet Autonomous Region. Alipay penetration/exposure and Hangzhou distance variables are May 2013 values, Yu'ebao penetration/exposure variables are December 2013 values, and deposit outflows are the cumulative fund flows from banks to Yu'ebao as of May 2014. All other stock variables are end-of-year values in 2012 and all change/growth variables are 2014 year-end minus 2012 year-end, if not otherwise specified.

\begin{tabular}{lccccc}
\hline \hline & \multicolumn{5}{c}{ A. Outcome variables } \\
\hline & count & mean & sd & min & $\max$ \\
fundflow_std & 323 & 100.000 & 285.940 & 0.108 & 3280.213 \\
balance_std & 323 & 100.000 & 302.821 & 0.188 & 3509.093 \\
\hline \multicolumn{5}{c}{ B. Key explanatory and instrumental variables } \\
\hline & count & mean & sd & min & $\max$ \\
penetration_YEB & 323 & 7.507 & 8.106 & 0.589 & 52.975 \\
penetration_Alipay & 323 & 8.371 & 7.086 & 1.148 & 41.849 \\
HZdistance & 365 & 1296.285 & 791.381 & 52.348 & 3849.885 \\
\hline \multicolumn{5}{c}{ C. City control variables } \\
\hline provincial_capital & count & mean & sd & min & max \\
branchshare_city & 334 & 0.082 & 0.275 & 0.000 & 1.000 \\
gdp & 333 & 1750.607 & 2415.745 & 25.630 & 20181.721 \\
population & 313 & 399.770 & 332.359 & 0.100 & 2945.000 \\
gdppc & 312 & 4.131 & 2.806 & 0.769 & 18.594 \\
gr_gdp_1214 & 333 & 8.241 & 5.068 & -16.648 & 20.249 \\
\hline \hline
\end{tabular}

(A) City-LEVEl SUMMARY STATS

\begin{tabular}{lccccc}
\hline \hline & \multicolumn{5}{c}{ A. Outcome variables } \\
\hline & count & mean & sd & min & $\max$ \\
bank_grdeposit & 131 & 17.154 & 9.688 & 0.224 & 66.740 \\
\hline & B. Key & explanatory & and & instrumental variables \\
\hline & count & mean & sd & min & max \\
exposureYEB_201312 & 143 & 14.076 & 11.035 & 0.718 & 45.889 \\
exposureAlipay_201305 & 143 & 13.852 & 8.708 & 0.654 & 36.974 \\
bank_lnHZdistance & 143 & 6.672 & 0.807 & 4.183 & 8.201 \\
\hline & \multicolumn{5}{c}{ C. Bank control variables } \\
\hline & count & mean & sd & min & max \\
lnsize & 131 & 16.105 & 1.732 & 13.204 & 21.285 \\
lndeposit & 132 & 15.769 & 1.693 & 12.734 & 21.034 \\
ratio_demanddeposit & 41 & 42.751 & 9.887 & 20.734 & 68.501 \\
ratio_hhdeposit & 39 & 27.564 & 12.398 & 8.246 & 59.117 \\
depositIBL & 131 & 81.470 & 13.572 & 45.762 & 100.000 \\
bank_branchshare & 143 & 0.492 & 2.446 & 0.002 & 22.277 \\
bank_lngdppc & 143 & 1.581 & 0.470 & 0.029 & 2.809 \\
bank_grgdppc & 141 & 6.360 & 3.204 & -5.533 & 17.725 \\
Net interest margin (NIM) & 126 & 3.387 & 1.017 & 1.592 & 7.488 \\
\hline \hline
\end{tabular}

(B) BANK-LEVEL SUMMARY STATS 
TABLE 2: First-STAge RegRESSIONS

Note: Column 1-2 show the first-stage regression results of using lagged Alipay penetration/exposure (May 2013 value) as IV for Yu'ebao penetration/exposure (December 2013 value), Column 3-4 show the first-stage regression results of using distance-to-Hangzhou as IV for Yu'ebao penetration/exposure (December 2013 value), and column 5-6 use both IVs. Results without and with controls are shown in odd and even columns, respectively. City- and bank-level controls take the values in December 2012. Standard errors are shown in parentheses. We use * for $\mathrm{p}<0.10$, ** for $\mathrm{p}<0.05$, and ${ }^{* * *}$ for $\mathrm{p}<0.010$.

\begin{tabular}{|c|c|c|c|c|c|c|}
\hline & \multicolumn{6}{|c|}{ Log of Yu'ebao Penetration (December 2013 value) } \\
\hline & (1) & $(2)$ & (3) & (4) & $(5)$ & $(6)$ \\
\hline $\ln$ (penetration_Alipay) & $\begin{array}{c}1.143^{* * *} \\
(0.014)\end{array}$ & $\begin{array}{c}1.105^{* * *} \\
(0.027)\end{array}$ & & & $\begin{array}{c}1.098^{* * *} \\
(0.016)\end{array}$ & $\begin{array}{c}1.045^{* * *} \\
(0.030)\end{array}$ \\
\hline $\ln ($ HZdistance $)$ & & & $\begin{array}{c}-0.579^{* * *} \\
(0.051)\end{array}$ & $\begin{array}{c}-0.352^{* * *} \\
(0.034)\end{array}$ & $\begin{array}{c}-0.097^{* * *} \\
(0.016)\end{array}$ & $\begin{array}{c}-0.090^{* * *} \\
(0.016)\end{array}$ \\
\hline provincial_capital & & $\begin{array}{c}0.006 \\
(0.038)\end{array}$ & & $\begin{array}{c}0.721^{* * *} \\
(0.088)\end{array}$ & & $\begin{array}{l}0.092^{* *} \\
(0.039)\end{array}$ \\
\hline $\ln$ (branchshare_city) & & $\begin{array}{l}-0.053 \\
(0.033)\end{array}$ & & $\begin{array}{c}0.103 \\
(0.084)\end{array}$ & & $\begin{array}{c}-0.078^{* *} \\
(0.032)\end{array}$ \\
\hline $\ln (\mathrm{gdp})$ & & $\begin{array}{c}0.046 \\
(0.040)\end{array}$ & & $\begin{array}{c}0.799^{* * *} \\
(0.064)\end{array}$ & & $\begin{array}{l}0.077^{* *} \\
(0.039)\end{array}$ \\
\hline $\ln$ (population) & & $\begin{array}{l}0.071^{*} \\
(0.037)\end{array}$ & & $\begin{array}{c}-0.769^{* * *} \\
(0.066)\end{array}$ & & $\begin{array}{c}0.038 \\
(0.035)\end{array}$ \\
\hline$N$ & 323 & 302 & 323 & 302 & 323 & 302 \\
\hline$R^{2}$ & 0.950 & 0.958 & 0.259 & 0.786 & 0.956 & 0.962 \\
\hline \multicolumn{7}{|c|}{ (A) City-Level First StAgE } \\
\hline & \multicolumn{6}{|c|}{ Log of Bank Exposure to Yu'ebao (December 2013 value) } \\
\hline & (1) & (2) & (3) & (4) & (5) & (6) \\
\hline $\ln$ (exposureAlipay) & $\begin{array}{c}1.182^{* * *} \\
(0.036)\end{array}$ & $\begin{array}{c}1.204^{* * *} \\
(0.038)\end{array}$ & & & $\begin{array}{c}1.116^{* * *} \\
(0.041)\end{array}$ & $\begin{array}{c}1.065^{* * *} \\
(0.046)\end{array}$ \\
\hline bank_lnHZdistance & & & $\begin{array}{c}-0.630^{* * *} \\
(0.060)\end{array}$ & $\begin{array}{c}-0.411^{* * *} \\
(0.039)\end{array}$ & $\begin{array}{c}-0.097^{* * * *} \\
(0.023)\end{array}$ & $\begin{array}{c}-0.116^{* * *} \\
(0.023)\end{array}$ \\
\hline $\ln ($ size $)$ & & $\begin{array}{c}0.123^{* * *} \\
(0.031)\end{array}$ & & $\begin{array}{c}0.339^{* * *} \\
(0.069)\end{array}$ & & $\begin{array}{c}0.125^{* * *} \\
(0.027)\end{array}$ \\
\hline ln(branchshare_bank) & & $\begin{array}{c}-0.102^{* * *} \\
(0.033)\end{array}$ & & $\begin{array}{c}-0.235^{* * *} \\
(0.073)\end{array}$ & & $\begin{array}{c}-0.096^{* * *} \\
(0.028)\end{array}$ \\
\hline depositIBL & & $\begin{array}{l}0.003^{*} \\
(0.001)\end{array}$ & & $\begin{array}{c}-0.008^{* *} \\
(0.004)\end{array}$ & & $\begin{array}{c}0.001 \\
(0.001)\end{array}$ \\
\hline bank_lngdppc & & $\begin{array}{l}-0.092^{*} \\
(0.050)\end{array}$ & & $\begin{array}{c}0.525^{* * *} \\
(0.072)\end{array}$ & & $\begin{array}{l}-0.039 \\
(0.043)\end{array}$ \\
\hline$N$ & 143 & 130 & 143 & 130 & 143 & 130 \\
\hline$R^{2}$ & 0.951 & 0.964 & 0.385 & 0.808 & 0.957 & 0.972 \\
\hline
\end{tabular}

(B) BANK-LEVEL FiRst StAGE 


\section{TABle 3: City-LeVel Funds into AND Holdings Of Yu’EBAO MMF}

Note: Column 1-2 shows the results of the baseline regressions, while the rest columns demonstrate the IV regression results using three sets of IVs: Column 3 displays the IV regression results using Alipay exposure prior to Yu'ebao, column 4 shows the IV results of distance to Hangzhou city, and column 5 using both IVs. Standard errors are shown in parentheses. We use ${ }^{*}$ for $\mathrm{p}<0.10,{ }^{* *}$ for $\mathrm{p}<0.05$, and ${ }^{* * *}$ for $\mathrm{p}<0.010$.

\begin{tabular}{|c|c|c|c|c|c|}
\hline & \multicolumn{5}{|c|}{ City-level Yu'ebao MMF Fund Inflows (June 2013-May 2014) } \\
\hline & (1) & (2) & (3) & $(4)$ & (5) \\
\hline & Baseline & Baseline & IV & IV & $I V$ \\
\hline & w/o controls & w/ controls & Alipay & HZdistance & Both \\
\hline $\ln$ (penetration_YEB) & $\begin{array}{c}1.527^{* * *} \\
(0.063)\end{array}$ & $\begin{array}{c}1.013^{* * *} \\
(0.034)\end{array}$ & $\begin{array}{c}0.987^{* * *} \\
(0.037)\end{array}$ & $\begin{array}{c}1.175^{* * *} \\
(0.068)\end{array}$ & $\begin{array}{c}0.999^{* * *} \\
(0.035)\end{array}$ \\
\hline provincial_capital & & $\begin{array}{c}-0.000 \\
(0.041)\end{array}$ & $\begin{array}{c}0.009 \\
(0.042)\end{array}$ & $\begin{array}{l}-0.059 \\
(0.045)\end{array}$ & $\begin{array}{c}0.005 \\
(0.042)\end{array}$ \\
\hline $\ln$ (branchshare_city) & & $\begin{array}{c}0.201^{* * *} \\
(0.047)\end{array}$ & $\begin{array}{c}0.210^{* * * *} \\
(0.048)\end{array}$ & $\begin{array}{l}0.146^{* *} \\
(0.060)\end{array}$ & $\begin{array}{c}0.206^{* * *} \\
(0.048)\end{array}$ \\
\hline $\ln (g d p)$ & & $\begin{array}{l}0.110^{* *} \\
(0.050)\end{array}$ & $\begin{array}{c}0.134^{* * *} \\
(0.050)\end{array}$ & $\begin{array}{c}-0.041 \\
(0.080)\end{array}$ & $\begin{array}{l}0.123^{* *} \\
(0.049)\end{array}$ \\
\hline $\ln$ (population) & & $\begin{array}{c}0.816^{* * *} \\
(0.053)\end{array}$ & $\begin{array}{c}0.789^{* * * *} \\
(0.058)\end{array}$ & $\begin{array}{c}0.979^{* * *} \\
(0.103)\end{array}$ & $\begin{array}{c}0.802^{* * *} \\
(0.059)\end{array}$ \\
\hline gr_gdp_1214 & & $\begin{array}{c}-0.004 \\
(0.003)\end{array}$ & $\begin{array}{l}-0.003 \\
(0.003)\end{array}$ & $\begin{array}{c}-0.010^{* *} \\
(0.004)\end{array}$ & $\begin{array}{l}-0.004 \\
(0.003)\end{array}$ \\
\hline$N$ & 323 & 302 & 302 & 302 & 302 \\
\hline Adjusted $R^{2}$ & 0.68 & 0.98 & 0.98 & 0.98 & 0.98 \\
\hline Weak id test & & & 1412.79 & 87.09 & 662.89 \\
\hline Overidentification test & & & 0.00 & 0.00 & 6.52 \\
\hline
\end{tabular}

(A) CitY-LEVEl FUndS INTO YU’EBAO MMF (JUNE 2013 - MAY 2014)

\begin{tabular}{|c|c|c|c|c|c|}
\hline & \multicolumn{5}{|c|}{ City-level Yu'ebao MMF Balance (June 2013-May 2014) } \\
\hline & $(1)$ & (2) & (3) & (4) & (5) \\
\hline & Baseline & Baseline & IV & IV & IV \\
\hline & w/o controls & $w /$ controls & Alipay & HZdistance & Both \\
\hline $\ln$ (penetration_YEB) & $\begin{array}{c}1.496^{* * *} \\
(0.059)\end{array}$ & $\begin{array}{c}1.006^{* * * *} \\
(0.027)\end{array}$ & $\begin{array}{c}0.968^{* * *} \\
(0.028)\end{array}$ & $\begin{array}{c}1.133^{* * * *} \\
(0.053)\end{array}$ & $\begin{array}{c}0.979^{* * *} \\
(0.028)\end{array}$ \\
\hline provincial_capital & & $\begin{array}{c}0.056 \\
(0.034)\end{array}$ & $\begin{array}{l}0.069^{* *} \\
(0.035)\end{array}$ & $\begin{array}{c}0.009 \\
(0.038)\end{array}$ & $\begin{array}{l}0.065^{*} \\
(0.035)\end{array}$ \\
\hline $\ln$ (branchshare_city) & & $\begin{array}{c}0.202^{* * * *} \\
(0.041)\end{array}$ & $\begin{array}{c}0.215^{* * *} \\
(0.041)\end{array}$ & $\begin{array}{c}0.159^{* * * *} \\
(0.049)\end{array}$ & $\begin{array}{c}0.212^{* * *} \\
(0.041)\end{array}$ \\
\hline $\ln (\mathrm{gdp})$ & & $\begin{array}{c}0.112^{* * * *} \\
(0.040)\end{array}$ & $\begin{array}{c}0.148^{* * *} \\
(0.039)\end{array}$ & $\begin{array}{l}-0.007 \\
(0.057)\end{array}$ & $\begin{array}{c}0.137^{* * *} \\
(0.039)\end{array}$ \\
\hline $\ln$ (population) & & $\begin{array}{c}0.722^{* * * *} \\
(0.043)\end{array}$ & $\begin{array}{c}0.684^{* * *} \\
(0.043)\end{array}$ & $\begin{array}{c}0.851^{* * * *} \\
(0.070)\end{array}$ & $\begin{array}{c}0.695^{* * *} \\
(0.043)\end{array}$ \\
\hline gr_gdp_1214 & & $\begin{array}{l}-0.004^{*} \\
(0.002)\end{array}$ & $\begin{array}{l}-0.003 \\
(0.002)\end{array}$ & $\begin{array}{c}-0.009^{* * *} \\
(0.003)\end{array}$ & $\begin{array}{l}-0.003 \\
(0.002)\end{array}$ \\
\hline$N$ & 323 & 302 & 302 & 302 & 302 \\
\hline Adjusted $R^{2}$ & 0.71 & 0.98 & 0.98 & 0.98 & 0.98 \\
\hline Weak id test & & & 1412.79 & 87.09 & 662.89 \\
\hline Overidentification test & & & 0.00 & 0.00 & 8.80 \\
\hline
\end{tabular}

(B) City-LeVEl YU’EBAO MMF BALANCE (AS OF MAY 2014) 


\section{Table 4: Bank Level Deposit Growth by Category: Household vs. Firm Deposits}

Note: This table shows the results for deposit growth separated by deposit segment: Households and Firms. Columns (1)-(4) show the results for households; Columns (5)-(8) show the results for firms. As before, Columns (1) and (5) are the baseline OLS regressions with controls; (2) and (6) are the IV regressions using Alipay exposure as an instrument for Yu'ebao exposure; (3) and (7) are the IV regressions using Hangzhou distance as an instrument for Yu'ebao exposure; (4) and (8) are the IV regressions using both instruments in the first stage. We use ${ }^{*}$ for $p<0.10,{ }^{* *}$ for $\mathrm{p}<0.05$, and ${ }^{* * *}$ for $\mathrm{p}<0.010$

\begin{tabular}{|c|c|c|c|c|c|c|c|c|}
\hline & \multicolumn{4}{|c|}{ Household deposit growth } & \multicolumn{4}{|c|}{ Firm deposit growth } \\
\hline & (1) & (2) & (3) & (4) & (5) & (6) & (7) & (8) \\
\hline & Baseline & IV & IV & $I V$ & Baseline & IV & IV & IV \\
\hline & $w /$ controls & Alipay & HZdistance & Both & $w /$ controls & Alipay & HZdistance & Both \\
\hline \multirow[t]{2}{*}{$\ln ($ exposureYEB) } & -7.206 & $-8.456^{*}$ & $-9.003^{*}$ & $-8.524^{*}$ & 1.315 & 1.088 & 3.070 & 1.354 \\
\hline & $(5.104)$ & $(4.698)$ & $(5.268)$ & $(4.634)$ & $(2.300)$ & $(2.196)$ & $(2.447)$ & $(2.110)$ \\
\hline \multirow[t]{2}{*}{$\ln$ (deposit_hh) } & 34.364 & 35.063 & 35.369 & 35.101 & & & & \\
\hline & $(32.983)$ & $(28.458)$ & $(28.013)$ & $(28.392)$ & & & & \\
\hline \multirow[t]{2}{*}{$\ln ($ deposit_firm) } & & & & & 2.322 & 2.490 & 1.029 & 2.294 \\
\hline & & & & & $(4.929)$ & $(4.296)$ & $(4.568)$ & $(4.284)$ \\
\hline \multirow[t]{2}{*}{ ln(ratio_hhdeposit) } & -29.747 & -30.332 & -30.588 & -30.364 & 3.052 & 3.120 & 2.529 & 3.041 \\
\hline & $(33.725)$ & $(28.965)$ & $(28.521)$ & $(28.901)$ & $(3.201)$ & $(2.771)$ & $(2.954)$ & $(2.787)$ \\
\hline \multirow[t]{2}{*}{$\ln ($ size $)$} & -34.876 & -35.253 & -35.417 & -35.273 & -3.787 & -3.947 & -2.554 & -3.760 \\
\hline & $(33.280)$ & $(28.728)$ & $(28.425)$ & $(28.686)$ & $(6.776)$ & $(5.920)$ & $(6.111)$ & $(5.908)$ \\
\hline \multirow{2}{*}{$\ln$ (branchshare_bank) } & -1.972 & -2.202 & -2.302 & -2.215 & -0.390 & -0.383 & -0.445 & -0.391 \\
\hline & (3.532) & $(3.210)$ & $(3.251)$ & (3.208) & $(2.669)$ & $(2.328)$ & (2.463) & $(2.342)$ \\
\hline \multirow[t]{2}{*}{ depositIBL } & -0.681 & $-0.684^{*}$ & $-0.685^{*}$ & $-0.684^{*}$ & $-0.289^{* *}$ & $-0.291^{* *}$ & $-0.272^{* *}$ & $-0.288^{* *}$ \\
\hline & $(0.475)$ & $(0.410)$ & $(0.407)$ & $(0.409)$ & $(0.134)$ & $(0.116)$ & $(0.119)$ & $(0.116)$ \\
\hline \multirow[t]{2}{*}{ bank_lngdppc } & 9.377 & 11.270 & 12.100 & 11.374 & 0.382 & 0.757 & -2.515 & 0.319 \\
\hline & $(9.762)$ & $(8.889)$ & $(9.751)$ & $(8.837)$ & $(6.102)$ & (5.593) & $(5.742)$ & $(5.484)$ \\
\hline \multirow[t]{2}{*}{ bank_grgdppc_1214 } & $1.001^{*}$ & $1.120^{* *}$ & $1.172^{* *}$ & $1.127^{* *}$ & $0.649^{* *}$ & $0.670^{* *}$ & 0.485 & $0.646^{* *}$ \\
\hline & $(0.561)$ & $(0.519)$ & $(0.572)$ & $(0.515)$ & $(0.316)$ & $(0.290)$ & $(0.326)$ & $(0.288)$ \\
\hline \multirow[t]{2}{*}{ Constant } & 225.611 & 222.137 & 220.616 & 221.947 & 44.516 & 44.302 & 46.172 & 44.552 \\
\hline & $(215.284)$ & $(186.460)$ & (187.015) & $(186.502)$ & $(52.458)$ & $(45.752)$ & $(48.868)$ & $(46.104)$ \\
\hline$N$ & 39 & 39 & 39 & 39 & 39 & 39 & 39 & 39 \\
\hline adj. $R^{2}$ & 0.34 & 0.33 & 0.33 & 0.33 & 0.37 & 0.37 & 0.35 & 0.37 \\
\hline Weak id test & & 419.26 & 24.93 & 328.66 & & 440.69 & 24.50 & 345.52 \\
\hline Overidentification test & & 0.00 & 0.00 & 0.02 & & 0.00 & 0.00 & 0.96 \\
\hline
\end{tabular}


Table 5: Bank Level Deposit Growth by Category: Household Demand vs. Time DePOSITS

Note: This table shows the results for household deposit growth separated by deposit type: Demand and Time. Columns (1)-(4) show the results for household demand deposits; Columns (5)-(8) show the results for household time deposits. As before, Columns (1) and (5) are the baseline OLS regressions with controls; (2) and (6) are the IV regressions using Alipay exposure as an instrument for Yu'ebao exposure; (3) and (7) are the IV regressions using Hangzhou distance as an instrument for Yu'ebao exposure; (4) and (8) are the IV regressions using both instruments in the fist stage. We use * for $\mathrm{p}<0.10,{ }^{* *}$ for $\mathrm{p}<0.05$, and ${ }^{* * *}$ for $\mathrm{p}<0.010$

\begin{tabular}{|c|c|c|c|c|c|c|c|c|}
\hline & \multicolumn{4}{|c|}{ HH Demand deposit growth } & \multicolumn{4}{|c|}{ HH Time deposit growth } \\
\hline & $(1)$ & (2) & (3) & (4) & (5) & (6) & (7) & (8) \\
\hline & Baseline & $I V$ & $I V$ & $I V$ & Baseline & $I V$ & $I V$ & $I V$ \\
\hline & $w /$ controls & Alipay & HZdistance & Both & $w /$ controls & Alipay & HZdistance & Both \\
\hline \multirow[t]{2}{*}{$\ln ($ exposureYEB) } & -11.799 & $-13.770^{*}$ & -9.662 & $-13.096^{*}$ & -4.265 & -5.296 & -8.361 & -5.732 \\
\hline & (8.136) & $(7.140)$ & (8.141) & $(7.209)$ & (5.998) & $(5.478)$ & (5.139) & $(5.217)$ \\
\hline \multirow[t]{2}{*}{ ln(deposit_hhdemand) } & -9.195 & -8.479 & -9.972 & -8.724 & & & & \\
\hline & (7.315) & $(6.346)$ & $(6.376)$ & $(6.322)$ & & & & \\
\hline \multirow[t]{2}{*}{ ln(deposit_hhtime) } & & & & & -17.355 & -17.976 & -19.821 & -18.238 \\
\hline & & & & & (13.007) & $(11.384)$ & $(12.466)$ & $(11.502)$ \\
\hline \multirow[t]{2}{*}{$\ln$ (ratio_hhdeposit) } & 10.061 & 9.557 & 10.607 & 9.729 & 19.644 & 20.347 & 22.437 & 20.644 \\
\hline & (7.472) & $(6.561)$ & $(6.558)$ & (6.535) & $(15.375)$ & $(13.413)$ & $(14.060)$ & $(13.481)$ \\
\hline \multirow[t]{2}{*}{$\ln ($ size $)$} & 1.690 & 1.595 & 1.792 & 1.628 & 17.050 & 17.967 & 20.693 & 18.355 \\
\hline & $(6.724)$ & $(5.940)$ & $(5.780)$ & $(5.901)$ & (15.233) & (13.390) & $(14.466)$ & $(13.477)$ \\
\hline \multirow[t]{2}{*}{$\ln$ (branchshare_bank) } & 8.243 & 7.751 & 8.777 & 7.919 & -3.299 & -3.523 & -4.189 & -3.618 \\
\hline & (7.903) & $(6.844)$ & $(6.892)$ & $(6.850)$ & $(5.289)$ & $(4.755)$ & $(4.927)$ & $(4.769)$ \\
\hline \multirow[t]{2}{*}{ depositIBL } & -0.145 & -0.150 & -0.140 & -0.148 & 0.011 & 0.023 & 0.060 & 0.028 \\
\hline & $(0.260)$ & $(0.228)$ & $(0.226)$ & $(0.227)$ & $(0.244)$ & $(0.212)$ & $(0.220)$ & $(0.212)$ \\
\hline \multirow[t]{2}{*}{ bank_lngdppc } & 26.312 & $29.401^{*}$ & 22.960 & $28.344^{*}$ & 3.929 & 5.591 & 10.530 & 6.294 \\
\hline & $(17.674)$ & $(15.457)$ & $(16.630)$ & $(15.494)$ & $(11.594)$ & $(10.258)$ & $(10.710)$ & $(10.043)$ \\
\hline \multirow[t]{2}{*}{ bank_grgdppc_1214 } & $2.190^{* *}$ & $2.339^{* * *}$ & $2.027^{* * *}$ & $2.288^{* * *}$ & 0.392 & 0.476 & 0.726 & 0.512 \\
\hline & $(0.824)$ & $(0.726)$ & $(0.767)$ & $(0.726)$ & $(0.803)$ & $(0.709)$ & $(0.691)$ & $(0.698)$ \\
\hline \multirow[t]{2}{*}{ Constant } & 81.589 & 72.721 & 91.209 & 75.754 & -82.755 & -93.622 & -125.927 & -98.218 \\
\hline & $(136.486)$ & $(118.134)$ & (119.872) & $(118.411)$ & $(165.284)$ & $(146.801)$ & $(152.946)$ & $(146.927)$ \\
\hline$N$ & 37 & 37 & 37 & 37 & 38 & 38 & 38 & 38 \\
\hline adj. $R^{2}$ & 0.21 & 0.21 & 0.21 & 0.21 & 0.30 & 0.30 & 0.28 & 0.30 \\
\hline $\mathrm{F}$ & 1.95 & 2.08 & 1.54 & 1.99 & 6.71 & 6.52 & 4.57 & 6.33 \\
\hline Weak id test & & 440.77 & 25.17 & 360.57 & & 411.92 & 25.26 & 316.73 \\
\hline Overidentification test & & 0.00 & 0.00 & 0.97 & & 0.00 & 0.00 & 0.53 \\
\hline
\end{tabular}


Table 6: Bank level Deposit Growth by Category: Household vs. Firm Deposits, LONGER HORIZON

Note: This table shows the results for deposit growth separated by deposit segment: Households and Firms during 2012-2015 and 2012-2016, respectively. Columns (1)-(4) show the results for households; Columns (5)-(8) show the results for firms. As before, Columns (1) and (5) are the baseline OLS regressions with controls; (2) and (6) are the IV regressions using Alipay exposure as an instrument for Yu'ebao exposure; (3) and (7) are the IV regressions using Hangzhou distance as an instrument for Yu'ebao exposure; (4) and (8) are the IV regressions using both instruments in the fist stage. We use ${ }^{*}$ for $\mathrm{p}<0.10,{ }^{* *}$ for $\mathrm{p}<0.05$, and ${ }^{* * *}$ for $\mathrm{p}<0.010$

\begin{tabular}{|c|c|c|c|c|c|c|c|c|c|c|c|c|c|c|c|c|}
\hline & $\begin{array}{c}(1) \\
\text { Baseline } \\
\text { w/ controls }\end{array}$ & $\begin{array}{c}(2) \\
I V \\
\text { Alipay }\end{array}$ & $\begin{array}{c}(3) \\
I V \\
\text { HZdistance } \\
\end{array}$ & $\begin{array}{l}\text { Household } \\
\text { (4) } \\
I V \\
\text { Both } \\
\end{array}$ & $\begin{array}{c}\text { deposit grow } \\
\text { (5) } \\
\text { Baseline } \\
\text { w/ controls } \\
\end{array}$ & $\begin{array}{c}\text { th } \\
\text { IV } \\
\text { IV } \\
\text { Alipay }\end{array}$ & $\begin{array}{c}(7) \\
I V \\
\text { HZdistance } \\
\end{array}$ & $\begin{array}{c}(8) \\
I V \\
\text { Both }\end{array}$ & $\begin{array}{c}\text { (9) } \\
\text { Baseline } \\
\text { w/ controls } \\
\end{array}$ & $\begin{array}{c}(10) \\
\text { IV } \\
\text { Alipay }\end{array}$ & $\begin{array}{c}(11) \\
\text { IV } \\
\text { HZdistance } \\
\end{array}$ & $\begin{array}{c}\text { Firm depo } \\
(12) \\
I V \\
\text { Both } \\
\end{array}$ & $\begin{array}{l}\text { sit growth } \\
\text { (13) } \\
\text { Baseline } \\
\text { w/ controls }\end{array}$ & $\begin{array}{c}(14) \\
\text { IV } \\
\text { Alipay }\end{array}$ & $\begin{array}{c}(15) \\
I V \\
\text { HZdistance } \\
\end{array}$ & $\begin{array}{c}(16) \\
I V \\
\text { Both }\end{array}$ \\
\hline $\ln ($ exposureYEB) & $\begin{array}{l}-8.313 \\
(5.946)\end{array}$ & $\begin{array}{c}-10.228^{*} \\
(5.600)\end{array}$ & $\begin{array}{l}-10.702^{*} \\
(6.013)\end{array}$ & $\begin{array}{c}-10.292^{*} \\
(5.399)\end{array}$ & $\begin{array}{l}-9.096 \\
(6.168)\end{array}$ & $\begin{array}{l}-10.848^{*} \\
(5.703)\end{array}$ & $\begin{array}{l}-7.726 \\
(8.016)\end{array}$ & $\begin{array}{l}-10.431^{*} \\
(5.664)\end{array}$ & $\begin{array}{l}.335 \\
(6.935)\end{array}$ & $\begin{array}{c}3.614 \\
(6.332)\end{array}$ & $\begin{array}{l}6.730 \\
(6.839)\end{array}$ & $\begin{array}{l}4.080 \\
(6.236)\end{array}$ & $\begin{array}{c}6.066 \\
(10.201)\end{array}$ & $\begin{array}{c}7.381 \\
(9.089)\end{array}$ & $\begin{array}{l}11.184 \\
(13.775)\end{array}$ & $\begin{array}{c}7.956 \\
(9.191)\end{array}$ \\
\hline $\ln$ (deposit_hh) & $\begin{array}{l}84.096^{* *} \\
(40.440)\end{array}$ & $\begin{array}{l}84.454^{* *} \\
(34.358)\end{array}$ & $\begin{array}{l}84.542^{* *} \\
(34.033)\end{array}$ & $\begin{array}{l}84.466 * * \\
(34.312)\end{array}$ & $\begin{array}{c}129.548^{* * * *} \\
(43.578)\end{array}$ & $\begin{array}{c}130.180^{* * * *} \\
(37.259)\end{array}$ & $\begin{array}{c}129.053^{* * * *} \\
(39.731)\end{array}$ & $\begin{array}{c}130.030^{* * *} \\
(37.567)\end{array}$ & & & & & & & & \\
\hline $\ln ($ deposit_firm) & & & & & & & & & $\begin{array}{c}3.267 \\
(13.456)\end{array}$ & $\begin{array}{c}3.050 \\
(11.933)\end{array}$ & $\begin{array}{c}0.626 \\
(11.738)\end{array}$ & $\begin{array}{c}2.688 \\
(11.836)\end{array}$ & $\begin{array}{c}-1.760 \\
(18.277)\end{array}$ & $\begin{array}{c}-2.700 \\
(16.260)\end{array}$ & $\begin{array}{c}-5.419 \\
(16.943)\end{array}$ & $\begin{array}{c}-3.112 \\
(16.129)\end{array}$ \\
\hline In(ratio_hhdeposit) & $\begin{array}{l}-78.044^{*} \\
(41.720)\end{array}$ & $\begin{array}{c}-78.204 * * \\
(35.321)\end{array}$ & $\begin{array}{c}-78.243^{* *} \\
(35.010)\end{array}$ & $\begin{array}{l}-78.209 * * \\
(35.278)\end{array}$ & $\begin{array}{c}-128.299^{* * *} \\
(44.707)\end{array}$ & $\begin{array}{c}-128.545^{* * * *} \\
(38.216)\end{array}$ & $\begin{array}{c}-128.106^{* * *} \\
(40.304)\end{array}$ & $\begin{array}{c}-128.487^{* * * *} \\
(38.478)\end{array}$ & $\begin{array}{l}5.193 \\
(9.037)\end{array}$ & $\begin{array}{c}5.101 \\
(7.885)\end{array}$ & $\begin{array}{l}4.070 \\
(7.936)\end{array}$ & $\begin{array}{l}4.947 \\
(7.881)\end{array}$ & $\begin{array}{c}1.290 \\
(12.483)\end{array}$ & $\begin{array}{c}0.734 \\
(10.867)\end{array}$ & $\begin{array}{c}-0.873 \\
(11.481)\end{array}$ & $\begin{array}{c}0.491 \\
(10.879)\end{array}$ \\
\hline $\ln ($ size $)$ & $\begin{array}{l}-85.938^{* *} \\
(40.795)\end{array}$ & $\begin{array}{c}-85.811^{* * *} \\
(34.680)\end{array}$ & $\begin{array}{l}-85.778^{* *} \\
(34.457)\end{array}$ & $\begin{array}{l}-85.805^{* *} \\
(34.649)\end{array}$ & $\begin{array}{c}-133.002^{* * *} \\
(43.714)\end{array}$ & $\begin{array}{c}-133.092^{* * *} \\
(37.369)\end{array}$ & $\begin{array}{c}-132.931^{* * *} \\
(39.261)\end{array}$ & $\begin{array}{c}-133.070^{* * *} \\
(37.601)\end{array}$ & $\begin{array}{c}-4.668 \\
(17.854)\end{array}$ & $\begin{array}{c}-4.454 \\
(15.849)\end{array}$ & $\begin{array}{c}-2.073 \\
(15.560)\end{array}$ & $\begin{array}{c}-4.098 \\
(15.753)\end{array}$ & $\begin{array}{c}-0.976 \\
(24.218)\end{array}$ & $\begin{array}{c}-0.156 \\
(21.577)\end{array}$ & $\begin{array}{c}2.217 \\
(21.491)\end{array}$ & $\begin{array}{c}0.204 \\
(21.422)\end{array}$ \\
\hline $\ln$ (branchshare_bank) & $\begin{array}{l}-2.142 \\
(4.297)\end{array}$ & $\begin{array}{l}-2.493 \\
(3.988)\end{array}$ & $\begin{array}{l}-2.579 \\
(3.798)\end{array}$ & $\begin{array}{l}-2.504 \\
(3.951)\end{array}$ & $\begin{array}{l}-2.227 \\
(5.476)\end{array}$ & $\begin{array}{l}-2.703 \\
(5.155)\end{array}$ & $\begin{array}{l}-1.855 \\
(5.134)\end{array}$ & $\begin{array}{l}-2.590 \\
(5.117)\end{array}$ & $\begin{array}{l}-2.386 \\
(5.425)\end{array}$ & $\begin{array}{l}-2.399 \\
(4.800)\end{array}$ & $\begin{array}{l}-2.542 \\
(5.025)\end{array}$ & $\begin{array}{l}-2.420 \\
(4.830)\end{array}$ & $\begin{array}{l}-1.701 \\
(7.822)\end{array}$ & $\begin{array}{l}-1.619 \\
(6.912)\end{array}$ & $\begin{array}{l}-1.382 \\
(7.491)\end{array}$ & $\begin{array}{l}-1.583 \\
(6.995)\end{array}$ \\
\hline depositIBL & $\begin{array}{l}-1.485^{* *} \\
(0.557)\end{array}$ & $\begin{array}{c}-1.479 * * * \\
(0.474)\end{array}$ & $\begin{array}{l}-1.478^{* * *} \\
(0.470)\end{array}$ & $\begin{array}{c}-1.479^{* * *} \\
(0.473)\end{array}$ & $\begin{array}{c}-1.938^{* * *} \\
(0.584)\end{array}$ & $\begin{array}{c}-1.928^{* * *} \\
(0.500)\end{array}$ & $\begin{array}{c}-1.945^{* * *} \\
(0.519)\end{array}$ & $\begin{array}{l}-1.931^{* * *} \\
(0.502)\end{array}$ & $\begin{array}{l}-0.362 \\
(0.322)\end{array}$ & $\begin{array}{l}-0.359 \\
(0.283)\end{array}$ & $\begin{array}{l}-0.328 \\
(0.284)\end{array}$ & $\begin{array}{l}-0.355 \\
(0.283)\end{array}$ & $\begin{array}{l}-0.519 \\
(0.512)\end{array}$ & $\begin{array}{l}-0.514 \\
(0.452)\end{array}$ & $\begin{array}{l}-0.499 \\
(0.440)\end{array}$ & $\begin{array}{l}-0.512 \\
(0.450)\end{array}$ \\
\hline bank_lngdppc & $\begin{array}{l}-0.436 \\
(9.642)\end{array}$ & $\begin{array}{l}2.360 \\
(9.008)\end{array}$ & $\begin{array}{c}3.053 \\
(9.908)\end{array}$ & $\begin{array}{c}2.454 \\
(8.797)\end{array}$ & $\begin{array}{l}-12.509 \\
(12.835)\end{array}$ & $\begin{array}{c}-9.910 \\
(11.645)\end{array}$ & $\begin{array}{l}-14.542 \\
(13.906)\end{array}$ & $\begin{array}{l}-10.528 \\
(11.519)\end{array}$ & $\begin{array}{l}-13.779 \\
(19.848)\end{array}$ & $\begin{array}{l}-14.226 \\
(17.909)\end{array}$ & $\begin{array}{l}-19.225 \\
(17.739)\end{array}$ & $\begin{array}{l}-14.974 \\
(17.717)\end{array}$ & $\begin{array}{l}-26.878 \\
(25.711)\end{array}$ & $\begin{array}{l}-29.000 \\
(23.120)\end{array}$ & $\begin{array}{l}-35.135 \\
(26.769)\end{array}$ & $\begin{array}{l}-29.928 \\
(22.924)\end{array}$ \\
\hline bank_grgdppc_1215 & $\begin{array}{c}0.434 \\
(0.535)\end{array}$ & $\begin{array}{c}0.572 \\
(0.510)\end{array}$ & $\begin{array}{c}0.606 \\
(0.546)\end{array}$ & $\begin{array}{c}0.576 \\
(0.501)\end{array}$ & & & & & $\begin{array}{c}0.328 \\
(0.750)\end{array}$ & $\begin{array}{c}0.308 \\
(0.652)\end{array}$ & $\begin{array}{c}0.083 \\
(0.784)\end{array}$ & $\begin{array}{c}0.274 \\
(0.665)\end{array}$ & & & & \\
\hline bank_grgdppc__1216 & & & & & $\begin{array}{c}0.238 \\
(0.270)\end{array}$ & $\begin{array}{c}0.307 \\
(0.259)\end{array}$ & $\begin{array}{c}0.184 \\
(0.326)\end{array}$ & $\begin{array}{c}0.291 \\
(0.255)\end{array}$ & & & & & $\begin{array}{c}-0.043 \\
(0.637)\end{array}$ & $\begin{array}{l}-0.095 \\
(0.518)\end{array}$ & $\begin{array}{l}-0.243 \\
(0.721)\end{array}$ & $\begin{array}{l}-0.117 \\
(0.535)\end{array}$ \\
\hline$N$ & 39 & 39 & 39 & 39 & 39 & 39 & 39 & 39 & 39 & 39 & 39 & 39 & 39 & 39 & 39 & 39 \\
\hline adj. $R^{2}$ & 0.45 & $\begin{array}{c}0.44 \\
346,05\end{array}$ & $\begin{array}{c}0.44 \\
2929\end{array}$ & $\begin{array}{c}0.44 \\
26676\end{array}$ & 0.57 & $\begin{array}{c}0.57 \\
261.04\end{array}$ & $\begin{array}{l}0.57 \\
1787\end{array}$ & $\begin{array}{c}0.57 \\
22669\end{array}$ & 0.14 & $\begin{array}{c}0.14 \\
357.95\end{array}$ & $\begin{array}{r}0.12 \\
28.35\end{array}$ & $\begin{array}{c}0.13 \\
273.31\end{array}$ & 0.14 & $\begin{array}{c}0.14 \\
24958\end{array}$ & $\begin{array}{c}0.13 \\
18.28\end{array}$ & $\begin{array}{c}0.13 \\
230.49\end{array}$ \\
\hline $\begin{array}{l}\text { Weak id test } \\
\text { Overidentification test }\end{array}$ & & $\begin{array}{c}346.05 \\
0.00\end{array}$ & $\begin{array}{c}29.29 \\
0.00\end{array}$ & $\begin{array}{c}266.76 \\
0.01\end{array}$ & & $\begin{array}{c}261.04 \\
0.00\end{array}$ & $\begin{array}{l}17.87 \\
0.00\end{array}$ & $\begin{array}{c}226.69 \\
0.26\end{array}$ & & $\begin{array}{c}357.95 \\
0.00\end{array}$ & $\begin{array}{c}28.35 \\
0.00\end{array}$ & $\begin{array}{c}273.31 \\
0.62\end{array}$ & & $\begin{array}{l}249.58 \\
0.00\end{array}$ & $\begin{array}{l}18.28 \\
0.00\end{array}$ & $\begin{array}{l}230.49 \\
0.13\end{array}$ \\
\hline
\end{tabular}


Table 7: Bank level Deposit Growth by Category: Household vs. Firm Deposits, Placebo Tests

Note: This table shows the results for deposit growth separated by deposit segment: Households and Firms during 2010-2012. Columns (1)-(4) show the results for households; Columns (5)-(8) show the results for firms. As before, Columns (1) and (5) are the baseline OLS regressions with controls; (2) and (6) are the IV regressions using Alipay exposure as an instrument for Yu'ebao exposure; (3) and (7) are the IV regressions using Hangzhou distance as an instrument for Yu'ebao exposure; (4) and (8) are the IV regressions using both instruments in the fist stage. We use * for $\mathrm{p}<0.10,{ }^{* *}$ for $\mathrm{p}<0.05$, and ${ }^{* *}$ for $\mathrm{p}<0.010$

\begin{tabular}{|c|c|c|c|c|c|c|c|c|}
\hline & \multicolumn{4}{|c|}{ Household deposit growth } & \multicolumn{4}{|c|}{ Firm deposit growth } \\
\hline & (1) & (2) & (3) & (4) & (5) & (6) & (7) & (8) \\
\hline & Baseline & $I V$ & $I V$ & $I V$ & Baseline & $I V$ & $I V$ & $I V$ \\
\hline & $w /$ controls & Alipay & HZdistance & Both & $w /$ controls & Alipay & HZdistance & Both \\
\hline $\ln ($ exposureYEB) & 2.241 & 2.612 & 1.995 & 2.573 & -2.391 & -2.116 & -0.731 & -2.022 \\
\hline & $(5.178)$ & $(4.396)$ & (6.802) & $(4.466)$ & $(2.796)$ & $(2.380)$ & $(2.939)$ & $(2.333)$ \\
\hline $\ln ($ deposit_hh) & $\begin{array}{c}50.934 \\
(70.518)\end{array}$ & $\begin{array}{c}50.774 \\
(61.759)\end{array}$ & $\begin{array}{c}51.041 \\
(62.055)\end{array}$ & $\begin{array}{c}50.791 \\
(61.776)\end{array}$ & & & & \\
\hline $\ln$ (deposit_firm) & & & & & $\begin{array}{c}31.836^{* * *} \\
(7.927)\end{array}$ & $\begin{array}{c}31.647^{* * *} \\
(6.940)\end{array}$ & $\begin{array}{c}30.698^{* * *} \\
(7.062)\end{array}$ & $\begin{array}{c}31.583^{* * *} \\
(6.937)\end{array}$ \\
\hline ln(ratio_hhdeposit) & $\begin{array}{l}-55.282 \\
(70.780)\end{array}$ & $\begin{array}{l}-55.007 \\
(61.935)\end{array}$ & $\begin{array}{l}-55.465 \\
(62.686)\end{array}$ & $\begin{array}{l}-55.036 \\
(61.979)\end{array}$ & $\begin{array}{c}8.599 \\
(5.753)\end{array}$ & $\begin{array}{l}8.626^{*} \\
(5.005)\end{array}$ & $\begin{array}{l}8.766^{*} \\
(5.051)\end{array}$ & $\begin{array}{l}8.636^{*} \\
(5.006)\end{array}$ \\
\hline $\ln ($ size $)$ & $\begin{array}{c}-53.601 \\
(71.365)\end{array}$ & $\begin{array}{l}-53.549 \\
(62.528)\end{array}$ & $\begin{array}{l}-53.635 \\
(62.399)\end{array}$ & $\begin{array}{l}-53.554 \\
(62.519)\end{array}$ & $\begin{array}{c}-32.197^{* * *} \\
(11.009)\end{array}$ & $\begin{array}{c}-32.034^{* * *} \\
(9.620)\end{array}$ & $\begin{array}{c}-31.209^{* * *} \\
(9.855)\end{array}$ & $\begin{array}{c}-31.978^{* * *} \\
(9.629)\end{array}$ \\
\hline $\ln$ (branchshare_bank) & $\begin{array}{c}0.715 \\
(2.950)\end{array}$ & $\begin{array}{c}0.789 \\
(2.604)\end{array}$ & $\begin{array}{c}0.665 \\
(2.623)\end{array}$ & $\begin{array}{c}0.781 \\
(2.596)\end{array}$ & $\begin{array}{l}-1.411 \\
(4.693)\end{array}$ & $\begin{array}{l}-1.409 \\
(4.116)\end{array}$ & $\begin{array}{l}-1.399 \\
(4.200)\end{array}$ & $\begin{array}{l}-1.409 \\
(4.121)\end{array}$ \\
\hline depositIBL & $\begin{array}{l}-1.040 \\
(1.075)\end{array}$ & $\begin{array}{l}-1.041 \\
(0.943)\end{array}$ & $\begin{array}{l}-1.040 \\
(0.935)\end{array}$ & $\begin{array}{l}-1.041 \\
(0.943)\end{array}$ & $\begin{array}{c}-0.731^{* * *} \\
(0.217)\end{array}$ & $\begin{array}{c}-0.729^{* * *} \\
(0.190)\end{array}$ & $\begin{array}{c}-0.720^{* * *} \\
(0.192)\end{array}$ & $\begin{array}{c}-0.728^{* * *} \\
(0.190)\end{array}$ \\
\hline bank_lngdppc & $\begin{array}{l}-15.491 \\
(9.476)\end{array}$ & $\begin{array}{c}-15.763^{*} \\
(8.507)\end{array}$ & $\begin{array}{c}-15.310^{*} \\
(8.257)\end{array}$ & $\begin{array}{c}-15.734^{*} \\
(8.455)\end{array}$ & $\begin{array}{c}-12.941^{*} \\
(6.632)\end{array}$ & $\begin{array}{c}-13.181^{* *} \\
(5.733)\end{array}$ & $\begin{array}{c}-14.393^{* *} \\
(6.321)\end{array}$ & $\begin{array}{c}-13.264^{* *} \\
(5.746)\end{array}$ \\
\hline bank_grgdppc_1012 & $\begin{array}{l}-0.910 \\
(0.951)\end{array}$ & $\begin{array}{l}-0.887 \\
(0.802)\end{array}$ & $\begin{array}{l}-0.925 \\
(0.932)\end{array}$ & $\begin{array}{l}-0.890 \\
(0.809)\end{array}$ & $\begin{array}{c}0.075 \\
(0.567)\end{array}$ & $\begin{array}{c}0.091 \\
(0.490)\end{array}$ & $\begin{array}{c}0.170 \\
(0.510)\end{array}$ & $\begin{array}{c}0.096 \\
(0.490)\end{array}$ \\
\hline$N$ & 38 & 38 & 38 & 38 & 38 & 38 & 38 & 38 \\
\hline adj. $R^{2}$ & 0.09 & 0.09 & 0.09 & 0.09 & 0.48 & 0.48 & 0.48 & 0.48 \\
\hline $\mathrm{F}$ & 2.59 & 2.58 & 2.43 & 2.58 & 7.28 & 7.16 & 6.73 & 7.19 \\
\hline Weak id test & & 309.29 & 20.01 & 218.54 & & 272.61 & 17.21 & 203.34 \\
\hline Overidentification test & & 0.00 & 0.00 & 0.02 & & 0.00 & 0.00 & 0.27 \\
\hline
\end{tabular}




\section{Table 8: Probability of Banks Distributing Yu’ebao-like Products}

Note: This table summarizes the results for banks' probabilities of distributing bao products (Yu'ebao-like MMFs) versus their exposure to Yu'ebao. Panel A and Panel B use a linear model and a hazard model on the time interval from Yu'ebao's introduction to Banks' (possible) launch of bao products, respectively. The observation window is between May 2013 and December 2017. In each Panel, Column (1) uses banks' exposure to Yu'ebao directly; Column (2), (3) and (4) are the "instrumented" results using predicted Yu' ebao exposure based on Alipay exposure, Hangzhou distance, and both, respectively. We use ${ }^{*}$ for $\mathrm{p}<0.10,{ }^{* *}$ for $\mathrm{p}<0.05$, and ${ }^{* * *}$ for $\mathrm{p}<0.010$.

\begin{tabular}{lcccc}
\hline \hline & $(1)$ & $(2)$ & $(3)$ & $(4)$ \\
& Baseline & IV & $I V$ & $I V$ \\
& & exposureAlipay & HZdistance & Both \\
\hline $\ln$ (exposureYEB) & $0.124^{* *}$ & $0.125^{*}$ & 0.152 & $0.129^{* *}$ \\
& $(0.062)$ & $(0.065)$ & $(0.092)$ & $(0.065)$ \\
& & & & \\
$\ln ($ size) & $0.220^{* * *}$ & $0.220^{* * *}$ & $0.207^{* *}$ & $0.218^{* * *}$ \\
& $(0.074)$ & $(0.074)$ & $(0.081)$ & $(0.074)$ \\
& & & & \\
$\ln$ (branchshare_bank) & -0.093 & -0.092 & -0.083 & -0.091 \\
& $(0.074)$ & $(0.074)$ & $(0.078)$ & $(0.074)$ \\
depositIBL & & & & \\
& 0.005 & 0.005 & 0.005 & 0.005 \\
bank_lngdppc & $(0.003)$ & $(0.003)$ & $(0.003)$ & $(0.003)$ \\
& & & & \\
& -0.058 & -0.059 & -0.076 & -0.062 \\
$N$ & $(0.080)$ & $(0.081)$ & $(0.091)$ & $(0.081)$ \\
adj. $R^{2}$ & & & & \\
\hline \hline
\end{tabular}

(A) LiNeAR Model

\begin{tabular}{lcccc}
\hline \hline & $(1)$ & $(2)$ & $(3)$ & $(4)$ \\
& Baseline & $\begin{array}{c}I V \\
\text { exposureAlipay }\end{array}$ & $\begin{array}{c}\text { IV } \\
\text { HZdistance }\end{array}$ & $\begin{array}{c}\text { IV } \\
\text { Both }\end{array}$ \\
\hline ln(exposureYEB) & $1.469^{* *}$ & $1.579^{* *}$ & $0.774^{*}$ & $1.497^{* *}$ \\
& $(0.585)$ & $(0.633)$ & $(0.410)$ & $(0.583)$ \\
& & & & \\
$\ln$ (size) & $1.089^{* *}$ & $1.209^{* * *}$ & $1.453^{* * *}$ & $1.216^{* * *}$ \\
& $(0.431)$ & $(0.421)$ & $(0.413)$ & $(0.418)$ \\
& & & & \\
$\ln$ (branchshare_bank) & -0.495 & -0.583 & $-0.771^{*}$ & -0.579 \\
& $(0.426)$ & $(0.421)$ & $(0.412)$ & $(0.419)$ \\
depositIBL & & & & \\
& 0.018 & 0.020 & 0.010 & 0.017 \\
bank_lngdppc & $(0.026)$ & $(0.026)$ & $(0.025)$ & $(0.026)$ \\
& & & & \\
& -0.654 & -0.767 & 0.296 & -0.701 \\
& $(0.817)$ & $(0.846)$ & $(0.678)$ & $(0.829)$ \\
$R^{2}$ & & & & \\
Wald Test (df =5) & 130 & 130 & 130 & 130 \\
\hline \hline
\end{tabular}

(B) HAZARd Model 


\section{TABLE 9: CHANGE IN YIELDS ON WMPS WITH HIGH MINIMUM INVESTMENT REQUIREMENT AND}

NO T+0 FAST REDEMPTION

Note: This table shows the impact of Yu'ebao exposure on banks' WMP yields and issuance. Column (1) regresses changes in bank WMP yields between 2012-2014 on Yu'ebao exposure. Columns (2)-(3) are IV specifications using Alipay exposure, Hangzhou distance, and both as instruments, respectively. Column (5) regresses changes in bank WMP issuance (in terms of number of WMP products) between 2012-2014 on Yu'ebao exposure. Columns (6)-(8) are

IV specifications. We use * for $\mathrm{p}<0.10,{ }^{* *}$ for $\mathrm{p}<0.05$, and ${ }^{* * *}$ for $\mathrm{p}<0.010$

\begin{tabular}{|c|c|c|c|c|c|c|c|c|}
\hline & \multicolumn{4}{|c|}{ Change in bank WMP yield, 2012-2014 } & \multicolumn{4}{|c|}{ Change in bank WMP issuance, 2012-2014 } \\
\hline & (1) & (2) & (3) & (4) & (5) & (6) & (7) & (8) \\
\hline & Baseline & IV & $I V$ & $I V$ & Baseline & $I V$ & $I V$ & $I V$ \\
\hline & $w /$ controls & Alipay & HZdistance & Both & $w /$ controls & Alipay & HZdistance & Both \\
\hline $\ln ($ exposureYEB) & -0.041 & -0.049 & 0.018 & -0.040 & 6.046 & 2.524 & 3.885 & 2.708 \\
\hline & $(0.072)$ & $(0.071)$ & $(0.100)$ & $(0.068)$ & $(8.053)$ & (7.419) & $(10.677)$ & $(7.398)$ \\
\hline wmpyield_2012 & $\begin{array}{c}-0.580^{* * *} \\
(0.123)\end{array}$ & $\begin{array}{c}-0.580^{* * *} \\
(0.117)\end{array}$ & $\begin{array}{c}-0.581^{* * *} \\
(0.116)\end{array}$ & $\begin{array}{c}-0.580^{* * *} \\
(0.117)\end{array}$ & & & & \\
\hline ln(wmpnumber_2012) & & & & & $\begin{array}{c}-22.073^{* * *} \\
(5.614)\end{array}$ & $\begin{array}{c}-21.867^{* * *} \\
(5.403)\end{array}$ & $\begin{array}{c}-21.947^{* * *} \\
(5.409)\end{array}$ & $\begin{array}{c}-21.878^{* * *} \\
(5.401)\end{array}$ \\
\hline $\ln ($ size $)$ & $\begin{array}{l}-0.025 \\
(0.065)\end{array}$ & $\begin{array}{l}-0.021 \\
(0.063)\end{array}$ & $\begin{array}{l}-0.046 \\
(0.063)\end{array}$ & $\begin{array}{c}-0.025 \\
(0.062)\end{array}$ & $\begin{array}{c}1.540 \\
(9.108)\end{array}$ & $\begin{array}{c}2.645 \\
(8.521)\end{array}$ & $\begin{array}{c}2.218 \\
(8.747)\end{array}$ & $\begin{array}{c}2.587 \\
(8.504)\end{array}$ \\
\hline ln(branchshare_bank) & $\begin{array}{c}-0.008 \\
(0.062)\end{array}$ & $\begin{array}{c}-0.011 \\
(0.060)\end{array}$ & $\begin{array}{c}0.009 \\
(0.059)\end{array}$ & $\begin{array}{c}-0.008 \\
(0.060)\end{array}$ & $\begin{array}{l}10.697 \\
(7.777)\end{array}$ & $\begin{array}{c}9.651 \\
(7.330)\end{array}$ & $\begin{array}{l}10.055 \\
(7.508)\end{array}$ & $\begin{array}{c}9.706 \\
(7.304)\end{array}$ \\
\hline depositIBL & $\begin{array}{l}-0.001 \\
(0.004)\end{array}$ & $\begin{array}{l}-0.001 \\
(0.003)\end{array}$ & $\begin{array}{l}-0.001 \\
(0.003)\end{array}$ & $\begin{array}{c}-0.001 \\
(0.003)\end{array}$ & $\begin{array}{l}-0.235 \\
(0.484)\end{array}$ & $\begin{array}{l}-0.230 \\
(0.458)\end{array}$ & $\begin{array}{l}-0.232 \\
(0.458)\end{array}$ & $\begin{array}{l}-0.230 \\
(0.458)\end{array}$ \\
\hline bank_lngdppc & $\begin{array}{c}0.120 \\
(0.093)\end{array}$ & $\begin{array}{c}0.126 \\
(0.088)\end{array}$ & $\begin{array}{c}0.085 \\
(0.110)\end{array}$ & $\begin{array}{c}0.120 \\
(0.089)\end{array}$ & $\begin{array}{c}13.728 \\
(13.682)\end{array}$ & $\begin{array}{c}15.775 \\
(13.034)\end{array}$ & $\begin{array}{c}14.984 \\
(14.284)\end{array}$ & $\begin{array}{c}15.668 \\
(13.106)\end{array}$ \\
\hline bank_grgdppc_1214 & $\begin{array}{c}-0.008 \\
(0.014)\end{array}$ & $\begin{array}{c}-0.007 \\
(0.013)\end{array}$ & $\begin{array}{l}-0.011 \\
(0.015)\end{array}$ & $\begin{array}{c}-0.008 \\
(0.014)\end{array}$ & $\begin{array}{l}-2.538 \\
(2.005)\end{array}$ & $\begin{array}{c}-2.362 \\
(1.898)\end{array}$ & $\begin{array}{l}-2.430 \\
(1.800)\end{array}$ & $\begin{array}{c}-2.371 \\
(1.879)\end{array}$ \\
\hline Constant & $\begin{array}{l}3.839^{* *} \\
(1.568)\end{array}$ & $\begin{array}{l}3.792^{* *} \\
(1.489)\end{array}$ & $\begin{array}{c}4.164^{* * *} \\
(1.491)\end{array}$ & $\begin{array}{c}3.846^{* * *} \\
(1.480)\end{array}$ & $\begin{array}{c}184.183 \\
(159.971)\end{array}$ & $\begin{array}{c}166.637 \\
(150.263)\end{array}$ & $\begin{array}{c}173.415 \\
(152.352)\end{array}$ & $\begin{array}{c}167.552 \\
(149.855)\end{array}$ \\
\hline$N$ & 81 & 81 & 81 & 81 & 83 & 83 & 83 & 83 \\
\hline adj. $R^{2}$ & 0.34 & 0.34 & 0.33 & 0.34 & 0.46 & 0.46 & 0.46 & 0.46 \\
\hline F & 5.83 & 5.72 & 5.56 & 5.71 & 8.08 & 8.03 & 8.16 & 8.02 \\
\hline Weak id test & & 389.78 & 92.92 & 420.73 & & 405.96 & 81.57 & 390.60 \\
\hline Overidentification test & & 0.00 & 0.00 & 0.51 & & 0.00 & 0.00 & 0.03 \\
\hline
\end{tabular}




\section{Table 10: FinTech Exposure and Bank Balance Sheet: Profits}

Note: This table shows the results for bank profitability and exposure to Yu'ebao. Columns (1)-(4) consider banks' change in net interest margin; Columns (5)-(8) consider banks' change in net interest spread. The regression is crosssectional at the bank level. As before, Columns (1) and (5) are the baseline OLS regressions with controls; (2) and (6) are the IV regressions using Alipay exposure as an instrument for Yu'ebao exposure; (3) and (7) are the IV regressions using Hangzhou distance as an instrument for Yu'ebao exposure; (4) and (8) are the IV regressions using both instruments in the fist stage. We use ${ }^{*}$ for $\mathrm{p}<0.10,{ }^{* *}$ for $\mathrm{p}<0.05$, and ${ }^{* * *}$ for $\mathrm{p}<0.010$

\begin{tabular}{|c|c|c|c|c|c|c|c|c|}
\hline & \multicolumn{4}{|c|}{ Change in net interest margin, 2012-2014 } & \multicolumn{4}{|c|}{ Change in NIS, 2012-2014 } \\
\hline & (1) & $(2)$ & (3) & $(4)$ & (5) & (6) & $(7)$ & (8) \\
\hline & Baseline & $I V$ & $I V$ & $I V$ & Baseline & $I V$ & $I V$ & $I V$ \\
\hline & $w /$ controls & Alipay & HZdistance & Both & $w /$ controls & Alipay & HZdistance & Both \\
\hline \multirow[t]{2}{*}{$\ln ($ exposureYEB) } & 0.128 & 0.040 & 0.129 & 0.054 & 0.196 & 0.148 & 0.277 & 0.167 \\
\hline & $(0.186)$ & $(0.168)$ & $(0.244)$ & $(0.174)$ & $(0.223)$ & $(0.204)$ & $(0.285)$ & $(0.206)$ \\
\hline \multirow[t]{2}{*}{ NIM } & $-0.495^{* * *}$ & $-0.495^{* * *}$ & $-0.495^{* * *}$ & $-0.495^{* * *}$ & & & & \\
\hline & $(0.151)$ & $(0.148)$ & $(0.146)$ & $(0.147)$ & & & & \\
\hline \multirow[t]{2}{*}{ NIS } & & & & & $-0.457^{* * *}$ & $-0.458^{* * *}$ & $-0.456^{* * *}$ & $-0.457^{* * *}$ \\
\hline & & & & & $(0.155)$ & $(0.150)$ & $(0.149)$ & $(0.150)$ \\
\hline \multirow[t]{2}{*}{$\ln ($ size $)$} & 0.001 & 0.040 & 0.001 & 0.034 & -0.041 & -0.020 & -0.077 & -0.029 \\
\hline & $(0.170)$ & $(0.169)$ & $(0.186)$ & $(0.170)$ & $(0.231)$ & $(0.227)$ & $(0.241)$ & $(0.227)$ \\
\hline \multirow[t]{2}{*}{ ln(branchshare_bank) } & -0.086 & -0.115 & -0.086 & -0.111 & -0.109 & -0.125 & -0.082 & -0.118 \\
\hline & $(0.168)$ & $(0.166)$ & $(0.173)$ & $(0.166)$ & $(0.240)$ & $(0.234)$ & $(0.238)$ & $(0.234)$ \\
\hline \multirow[t]{2}{*}{ depositIBL } & 0.003 & 0.003 & 0.003 & 0.003 & -0.004 & -0.004 & -0.004 & -0.004 \\
\hline & $(0.012)$ & $(0.011)$ & $(0.011)$ & $(0.011)$ & $(0.014)$ & $(0.013)$ & $(0.013)$ & $(0.013)$ \\
\hline \multirow[t]{2}{*}{ bank_lngdppc } & -0.419 & -0.366 & -0.420 & -0.374 & -0.530 & -0.501 & -0.580 & -0.513 \\
\hline & $(0.306)$ & $(0.287)$ & $(0.308)$ & $(0.288)$ & $(0.364)$ & $(0.343)$ & $(0.374)$ & $(0.346)$ \\
\hline \multirow[t]{2}{*}{ bank_grgdppc_1214 } & 0.017 & 0.022 & 0.017 & 0.021 & -0.009 & -0.007 & -0.014 & -0.008 \\
\hline & $(0.030)$ & $(0.029)$ & $(0.029)$ & $(0.029)$ & $(0.040)$ & $(0.039)$ & $(0.039)$ & $(0.038)$ \\
\hline \multirow[t]{2}{*}{ Constant } & 1.181 & 0.583 & 1.189 & 0.676 & 2.553 & 2.229 & 3.100 & 2.362 \\
\hline & $(3.751)$ & $(3.687)$ & (3.869) & (3.697) & (5.109) & $(4.984)$ & (5.156) & $(4.987)$ \\
\hline$N$ & 123 & 123 & 123 & 123 & 123 & 123 & 123 & 123 \\
\hline adj. $R^{2}$ & 0.23 & 0.23 & 0.23 & 0.23 & 0.16 & 0.16 & 0.16 & 0.16 \\
\hline F & 3.07 & 2.97 & 3.10 & 2.99 & 2.27 & 2.25 & 2.32 & 2.26 \\
\hline Weak id test & & 903.42 & 110.61 & 730.61 & & 887.17 & 110.35 & 739.20 \\
\hline Overidentification test & & 0.00 & 0.00 & 0.32 & & 0.00 & 0.00 & 0.40 \\
\hline
\end{tabular}


Table 11: FinTech Exposure and Bank Profits: Core Business, 2012-2014

Note: This table examines the decomposition of banks' core business profits. The \%Change in $\mathrm{x}$ is defined as (2014 value of $x-2012$ value of $x$ ) / 2012 total assets of the bank. Standard errors in parentheses. We use ${ }^{*}$ for $p<0.10,{ }^{* *}$ for $\mathrm{p}<0.05$, and ${ }^{* * *}$ for $\mathrm{p}<0.010$.

\begin{tabular}{|c|c|c|c|c|c|c|c|c|c|c|c|c|}
\hline & \multicolumn{4}{|c|}{ \%Change in core profits } & \multicolumn{4}{|c|}{ \%Change in core revenue } & \multicolumn{4}{|c|}{ \%Change in core expenditure } \\
\hline & (1) & (2) & (3) & (4) & (5) & (6) & (7) & (8) & (9) & (10) & (11) & (12) \\
\hline $\ln$ (exposureYEB) & $\begin{array}{c}-0.340^{* *} \\
(0.170)\end{array}$ & $\begin{array}{c}-0.390^{* *} \\
(0.166)\end{array}$ & $\begin{array}{c}-0.251 \\
(0.246)\end{array}$ & $\begin{array}{c}-0.368^{* *} \\
(0.170)\end{array}$ & $\begin{array}{l}-0.197 \\
(0.261)\end{array}$ & $\begin{array}{c}-0.301 \\
(0.242)\end{array}$ & $\begin{array}{c}0.300 \\
(0.401)\end{array}$ & $\begin{array}{l}-0.206 \\
0.257)\end{array}$ & 0.093 & $\begin{array}{c}0.054 \\
(0125)\end{array}$ & $0.503^{* *}$ & 0.118 \\
\hline base_profit_core & $\begin{array}{c}-0.413^{* *} \\
(0.195)\end{array}$ & $\begin{array}{c}-0.420^{* *} \\
(0.191)\end{array}$ & $\begin{array}{c}-0.401^{* *} \\
(0.181)\end{array}$ & $\begin{array}{c}-0.417^{* *} \\
(0.190)\end{array}$ & & & & & & & & \\
\hline base_revenue_core & & & & & $\begin{array}{l}-0.271 \\
(0.223)\end{array}$ & $\begin{array}{l}-0.273 \\
(0.220)\end{array}$ & $\begin{array}{l}-0.259 \\
(0.197)\end{array}$ & $\begin{array}{l}-0.271 \\
(0.216)\end{array}$ & & & & \\
\hline base_expend_core & & & & & & & & & $\begin{array}{l}-0.132 \\
(0.154)\end{array}$ & $\begin{array}{l}-0.127 \\
(0.152)\end{array}$ & $\begin{array}{l}-0.181 \\
(0.136)\end{array}$ & $\begin{array}{l}-0.135 \\
(0.149)\end{array}$ \\
\hline $\ln ($ size $)$ & $\begin{array}{c}0.056 \\
(0.146)\end{array}$ & $\begin{array}{c}0.078 \\
(0.147)\end{array}$ & $\begin{array}{c}0.016 \\
(0.178)\end{array}$ & $\begin{array}{c}0.069 \\
(0.150)\end{array}$ & $\begin{array}{l}-0.195 \\
(0.225)\end{array}$ & $\begin{array}{l}-0.149 \\
(0.223)\end{array}$ & $\begin{array}{l}-0.416 \\
(0.274)\end{array}$ & $\begin{array}{l}-0.191 \\
(0.228)\end{array}$ & $\begin{array}{l}-0.203 \\
(0.128)\end{array}$ & $\begin{array}{l}-0.185 \\
(0.127)\end{array}$ & $\begin{array}{c}-0.396^{* * *} \\
(0.146)\end{array}$ & $\begin{array}{l}-0.215^{*} \\
(0.128)\end{array}$ \\
\hline $\ln$ (branchshare_bank) & $\begin{array}{l}-0.150 \\
(0.138)\end{array}$ & $\begin{array}{l}-0.167 \\
(0.138)\end{array}$ & $\begin{array}{l}-0.120 \\
(0.154)\end{array}$ & $\begin{array}{l}-0.160 \\
(0.139)\end{array}$ & $\begin{array}{l}-0.063 \\
(0.200)\end{array}$ & $\begin{array}{c}-0.098 \\
(0.198)\end{array}$ & $\begin{array}{c}0.102 \\
(0.223)\end{array}$ & $\begin{array}{l}-0.066 \\
(0.199)\end{array}$ & $\begin{array}{c}0.050 \\
(0.120)\end{array}$ & $\begin{array}{c}0.036 \\
(0.118)\end{array}$ & $\begin{array}{c}0.193 \\
(0.126)\end{array}$ & $\begin{array}{c}0.058 \\
(0.118)\end{array}$ \\
\hline depositIBL & $\begin{array}{c}0.010 \\
(0.007)\end{array}$ & $\begin{array}{c}0.010 \\
(0.007)\end{array}$ & $\begin{array}{c}0.010 \\
(0.007)\end{array}$ & $\begin{array}{c}0.010 \\
(0.007)\end{array}$ & $\begin{array}{c}0.006 \\
(0.013)\end{array}$ & $\begin{array}{c}0.006 \\
(0.012)\end{array}$ & $\begin{array}{c}0.007 \\
(0.012)\end{array}$ & $\begin{array}{c}0.006 \\
(0.012)\end{array}$ & $\begin{array}{l}-0.004 \\
(0.006)\end{array}$ & $\begin{array}{l}-0.004 \\
(0.006)\end{array}$ & $\begin{array}{l}-0.002 \\
(0.006)\end{array}$ & $\begin{array}{l}-0.004 \\
(0.006)\end{array}$ \\
\hline bank_lngdppc & $\begin{array}{l}-0.172 \\
(0.221)\end{array}$ & $\begin{array}{l}-0.142 \\
(0.203)\end{array}$ & $\begin{array}{l}-0.226 \\
(0.242)\end{array}$ & $\begin{array}{l}-0.155 \\
(0.207)\end{array}$ & $\begin{array}{l}-0.161 \\
(0.304)\end{array}$ & $\begin{array}{l}-0.097 \\
(0.271)\end{array}$ & $\begin{array}{l}-0.468 \\
(0.355)\end{array}$ & $\begin{array}{l}-0.156 \\
(0.280)\end{array}$ & $\begin{array}{c}0.008 \\
(0.130)\end{array}$ & $\begin{array}{c}0.031 \\
(0.121)\end{array}$ & $\begin{array}{l}-0.236 \\
(0.167)\end{array}$ & $\begin{array}{l}-0.007 \\
(0.123)\end{array}$ \\
\hline bank_grgdppc_1214 & $\begin{array}{l}0.046^{* *} \\
(0.022)\end{array}$ & $\begin{array}{l}0.049^{* *} \\
(0.022)\end{array}$ & $\begin{array}{l}0.042^{*} \\
(0.022)\end{array}$ & $\begin{array}{l}0.048^{* *} \\
(0.022)\end{array}$ & $\begin{array}{c}0.053 \\
(0.033)\end{array}$ & $\begin{array}{l}0.058^{*} \\
(0.031)\end{array}$ & $\begin{array}{c}0.027 \\
(0.035)\end{array}$ & $\begin{array}{l}0.053^{*} \\
(0.032)\end{array}$ & $\begin{array}{c}0.009 \\
(0.018)\end{array}$ & $\begin{array}{c}0.011 \\
(0.017)\end{array}$ & $\begin{array}{c}-0.012 \\
(0.020)\end{array}$ & $\begin{array}{c}0.008 \\
(0.017)\end{array}$ \\
\hline Observ & 127 & 127 & 127 & 127 & 127 & 127 & 127 & 127 & 127 & 127 & 127 & 127 \\
\hline Adjusted R-squared & 0.18 & 0.18 & 0.18 & 0.18 & 0.14 & 0.14 & 0.11 & 0.14 & 0.08 & 0.08 & -0.00 & 0.08 \\
\hline $\mathrm{F}$ & 2.66 & 2.79 & 2.69 & 2.80 & 3.42 & 3.46 & 3.33 & 3.45 & 3.17 & 2.99 & 3.68 & 3.10 \\
\hline Weak id test & & 867.94 & 113.63 & 726.36 & & 934.99 & 118.38 & 748.56 & & 914.75 & 99.27 & 672.99 \\
\hline Overidentification test & & 0.00 & 0.00 & 0.70 & & 0.00 & 0.00 & 5.62 & & 0.00 & 0.00 & 10.54 \\
\hline
\end{tabular}

Table 12: FinTech Exposure ANd BANK Profits: Interest Business, 2012-2014

Note: This table examines the decomposition of banks' interest rate related business, a key part of banks' core business. The \%Change in $x$ is defined as (2014 value of $x-2012$ value of $x) / 2012$ total assets of the bank. Standard errors in parentheses. We use ${ }^{*}$ for $\mathrm{p}<0.10,{ }^{* *}$ for $\mathrm{p}<0.05$, and ${ }^{* * *}$ for $\mathrm{p}<0.010$.

\begin{tabular}{|c|c|c|c|c|c|c|c|c|c|c|c|c|}
\hline & \multicolumn{4}{|c|}{ \%Change in interest profits } & \multicolumn{4}{|c|}{ \%Change in interest revenue } & \multicolumn{4}{|c|}{ \%Change in interest expenditure } \\
\hline & (1) & (2) & (3) & (4) & (5) & (6) & (7) & (8) & (9) & $(10)$ & (11) & (12) \\
\hline $\ln ($ exposureYEB) & 0.115 & -0.030 & 0.357 & 0.029 & 0.289 & 0.119 & 1.157 & 0.279 & 0.183 & 0.162 & 0.751 & 0.254 \\
\hline & $(0.264)$ & $(0.243)$ & $(0.376)$ & $(0.254)$ & $(0.513)$ & $(0.471)$ & $(0.796)$ & $(0.497)$ & $(0.378)$ & $(0.336)$ & $(0.588)$ & $(0.359)$ \\
\hline base_profit_interest & $\begin{array}{l}-0.317 \\
(0.213)\end{array}$ & $\begin{array}{l}-0.317 \\
(0.210)\end{array}$ & $\begin{array}{l}-0.316 \\
(0.199)\end{array}$ & $\begin{array}{l}-0.317 \\
(0.208)\end{array}$ & & & & & & & & \\
\hline base_revenue_interest & & & & & $\begin{array}{c}-0.659^{* * * *} \\
(0.172)\end{array}$ & $\begin{array}{c}-0.664^{* * * *} \\
(0.168)\end{array}$ & $\begin{array}{c}-0.634^{* * *} \\
(0.164)\end{array}$ & $\begin{array}{c}-0.659^{* * *} \\
(0.166)\end{array}$ & & & & \\
\hline base_expend_interest & & & & & & & & & $\begin{array}{c}-0.623^{* * *} \\
(0.204)\end{array}$ & $\begin{array}{c}-0.624^{* * *} \\
(0.197)\end{array}$ & $\begin{array}{c}-0.591^{* * *} \\
(0.193)\end{array}$ & $\begin{array}{c}-0.619^{* * *} \\
(0.196)\end{array}$ \\
\hline $\ln ($ size $)$ & $\begin{array}{c}0.034 \\
(0.233)\end{array}$ & $\begin{array}{c}0.099 \\
(0.233)\end{array}$ & $\begin{array}{l}-0.074 \\
(0.275)\end{array}$ & $\begin{array}{c}0.073 \\
(0.237)\end{array}$ & $\begin{array}{l}-0.156 \\
(0.377)\end{array}$ & $\begin{array}{l}-0.079 \\
(0.384)\end{array}$ & $\begin{array}{l}-0.546 \\
(0.455)\end{array}$ & $\begin{array}{l}-0.151 \\
(0.385)\end{array}$ & $\begin{array}{l}-0.143 \\
(0.267)\end{array}$ & $\begin{array}{l}-0.133 \\
(0.274)\end{array}$ & $\begin{array}{l}-0.403 \\
(0.311)\end{array}$ & $\begin{array}{l}-0.175 \\
(0.271)\end{array}$ \\
\hline $\ln$ (branchshare_bank) & $\begin{array}{l}-0.235 \\
(0.226)\end{array}$ & $\begin{array}{l}-0.284 \\
(0.227)\end{array}$ & $\begin{array}{l}-0.154 \\
(0.244)\end{array}$ & $\begin{array}{l}-0.264 \\
(0.228)\end{array}$ & $\begin{array}{l}-0.456 \\
(0.380)\end{array}$ & $\begin{array}{l}-0.513 \\
(0.385)\end{array}$ & $\begin{array}{l}-0.162 \\
(0.396)\end{array}$ & $\begin{array}{l}-0.459 \\
(0.379)\end{array}$ & $\begin{array}{l}-0.238 \\
(0.270)\end{array}$ & $\begin{array}{l}-0.245 \\
(0.271)\end{array}$ & $\begin{array}{l}-0.041 \\
(0.276)\end{array}$ & $\begin{array}{l}-0.213 \\
(0.266)\end{array}$ \\
\hline depositIBL & $\begin{array}{c}0.006 \\
(0.014)\end{array}$ & $\begin{array}{c}0.006 \\
(0.014)\end{array}$ & $\begin{array}{c}0.007 \\
(0.013)\end{array}$ & $\begin{array}{c}0.006 \\
(0.014)\end{array}$ & $\begin{array}{l}-0.005 \\
(0.022)\end{array}$ & $\begin{array}{l}-0.005 \\
(0.022)\end{array}$ & $\begin{array}{l}-0.004 \\
(0.021)\end{array}$ & $\begin{array}{l}-0.005 \\
(0.021)\end{array}$ & $\begin{array}{l}-0.023 \\
(0.015)\end{array}$ & $\begin{array}{l}-0.023 \\
(0.015)\end{array}$ & $\begin{array}{l}-0.022 \\
(0.015)\end{array}$ & $\begin{array}{l}-0.023 \\
(0.015)\end{array}$ \\
\hline bank_lngdppc & $\begin{array}{l}-0.407 \\
(0.373)\end{array}$ & $\begin{array}{l}-0.318 \\
(0.350)\end{array}$ & $\begin{array}{l}-0.556 \\
(0.386)\end{array}$ & $\begin{array}{l}-0.354 \\
(0.352)\end{array}$ & $\begin{array}{l}-0.357 \\
(0.976)\end{array}$ & $\begin{array}{l}-0.252 \\
(0.914)\end{array}$ & $\begin{array}{l}-0.896 \\
(1.058)\end{array}$ & $\begin{array}{l}-0.351 \\
(0.931)\end{array}$ & $\begin{array}{l}-0.048 \\
(0.797)\end{array}$ & $\begin{array}{l}-0.034 \\
(0.738)\end{array}$ & $\begin{array}{l}-0.396 \\
(0.870)\end{array}$ & $\begin{array}{l}-0.091 \\
(0.756)\end{array}$ \\
\hline bank_grgdppc_1214 & $\begin{array}{c}0.033 \\
(0.036)\end{array}$ & $\begin{array}{c}0.041 \\
(0.035)\end{array}$ & $\begin{array}{c}0.020 \\
(0.036)\end{array}$ & $\begin{array}{c}0.038 \\
(0.035)\end{array}$ & $\begin{array}{l}-0.087 \\
(0.094)\end{array}$ & $\begin{array}{c}-0.078 \\
(0.091)\end{array}$ & $\begin{array}{l}-0.132 \\
(0.100)\end{array}$ & $\begin{array}{l}-0.086 \\
(0.092)\end{array}$ & $\begin{array}{l}-0.124^{*} \\
(0.072)\end{array}$ & $\begin{array}{l}-0.123^{*} \\
(0.069)\end{array}$ & $\begin{array}{c}-0.153^{* *} \\
(0.077)\end{array}$ & $\begin{array}{l}-0.127^{*} \\
(0.070)\end{array}$ \\
\hline Observations & 127 & 127 & 127 & 127 & 126 & 126 & 126 & 126 & 126 & 126 & 126 & 126 \\
\hline Adjusted R-squared & 0.07 & 0.07 & 0.06 & 0.07 & 0.20 & 0.20 & 0.17 & 0.20 & 0.15 & 0.15 & 0.14 & 0.15 \\
\hline F & 1.83 & 1.77 & 1.94 & 1.80 & 3.53 & 3.52 & 3.78 & 3.58 & 3.65 & 3.57 & 4.14 & 3.66 \\
\hline Weak id test & & 925.90 & 113.04 & 740.59 & & 983.25 & 121.10 & 760.68 & & 936.66 & 127.87 & 720.87 \\
\hline Overidentification test & & 0.00 & 0.00 & 2.65 & & 0.00 & 0.00 & 3.80 & & 0.00 & 0.00 & 2.37 \\
\hline
\end{tabular}




\section{TABle 13: FinTech Exposure and Bank Balance SheEt: Risks}

Note: This table shows the results for bank risk-taking measures. Columns (1)-(4) consider banks' change in bad loan ratios; Columns (5)-(8) consider banks' change in risky asset ratios. The regression is cross-sectional at the bank level. As before, Columns (1) and (5) are the baseline OLS regressions with controls; (2) and (6) are the IV regressions using Alipay exposure as an instrument for Yu'ebao exposure; (3) and (7) are the IV regressions using Hangzhou distance as an instrument for Yu'ebao exposure; (4) and (8) are the IV regressions using both instruments in the fist stage. We use * for $\mathrm{p}<0.10,{ }^{* *}$ for $\mathrm{p}<0.05$, and ${ }^{* * *}$ for $\mathrm{p}<0.010$

\begin{tabular}{|c|c|c|c|c|c|c|c|c|}
\hline & \multicolumn{4}{|c|}{ Change in bad loan ratio, 2012-2014 } & \multicolumn{4}{|c|}{ Change in risky asset ratio, 2012-2014 } \\
\hline & $(1)$ & $(2)$ & (3) & (4) & (5) & $(6)$ & (7) & $(8)$ \\
\hline & Baseline & $I V$ & $I V$ & $I V$ & Baseline & $I V$ & $I V$ & $I V$ \\
\hline & $w /$ controls & Alipay & HZdistance & Both & $w /$ controls & Alipay & HZdistance & Both \\
\hline $\ln ($ exposureYEB) & $\begin{array}{l}-0.012 \\
(0.114)\end{array}$ & $\begin{array}{l}-0.064 \\
(0.120)\end{array}$ & $\begin{array}{c}0.074 \\
(0.166)\end{array}$ & $\begin{array}{l}-0.043 \\
(0.121)\end{array}$ & $\begin{array}{c}-3.263^{* *} \\
(1.568)\end{array}$ & $\begin{array}{c}-3.967^{* *} \\
(1.650)\end{array}$ & $\begin{array}{l}-3.204 \\
(2.521)\end{array}$ & $\begin{array}{c}-3.873^{* *} \\
(1.641)\end{array}$ \\
\hline ratio_badloan & $\begin{array}{c}-0.356^{* * *} \\
(0.126)\end{array}$ & $\begin{array}{c}-0.343^{* * *} \\
(0.127)\end{array}$ & $\begin{array}{c}-0.380^{* * *} \\
(0.124)\end{array}$ & $\begin{array}{c}-0.348^{* * *} \\
(0.126)\end{array}$ & & & & \\
\hline ratio_riskyassets & & & & & $\begin{array}{c}-0.221^{* *} \\
(0.088)\end{array}$ & $\begin{array}{c}-0.216^{* * *} \\
(0.084)\end{array}$ & $\begin{array}{c}-0.222^{* *} \\
(0.090)\end{array}$ & $\begin{array}{c}-0.217^{* *} \\
(0.084)\end{array}$ \\
\hline $\ln ($ size $)$ & $\begin{array}{l}-0.044 \\
(0.099)\end{array}$ & $\begin{array}{c}-0.022 \\
(0.100)\end{array}$ & $\begin{array}{l}-0.081 \\
(0.109)\end{array}$ & $\begin{array}{l}-0.031 \\
(0.100)\end{array}$ & $\begin{array}{l}-1.651 \\
(1.538)\end{array}$ & $\begin{array}{l}-1.380 \\
(1.505)\end{array}$ & $\begin{array}{l}-1.674 \\
(1.662)\end{array}$ & $\begin{array}{l}-1.416 \\
(1.502)\end{array}$ \\
\hline ln(branchshare_bank) & $\begin{array}{c}0.035 \\
(0.100)\end{array}$ & $\begin{array}{c}0.019 \\
(0.100)\end{array}$ & $\begin{array}{c}0.062 \\
(0.103)\end{array}$ & $\begin{array}{c}0.025 \\
(0.100)\end{array}$ & $\begin{array}{c}0.801 \\
(1.685)\end{array}$ & $\begin{array}{c}0.588 \\
(1.651)\end{array}$ & $\begin{array}{c}0.819 \\
(1.638)\end{array}$ & $\begin{array}{c}0.616 \\
(1.635)\end{array}$ \\
\hline depositIBL & $\begin{array}{c}0.000 \\
(0.005)\end{array}$ & $\begin{array}{c}0.000 \\
(0.005)\end{array}$ & $\begin{array}{c}0.001 \\
(0.005)\end{array}$ & $\begin{array}{c}0.000 \\
(0.005)\end{array}$ & $\begin{array}{c}-0.330^{* * *} \\
(0.085)\end{array}$ & $\begin{array}{c}-0.335^{* * *} \\
(0.081)\end{array}$ & $\begin{array}{c}-0.330^{* * *} \\
(0.078)\end{array}$ & $\begin{array}{c}-0.334^{* * *} \\
(0.081)\end{array}$ \\
\hline bank_lngdppc & $\begin{array}{c}0.166 \\
(0.174)\end{array}$ & $\begin{array}{c}0.194 \\
(0.168)\end{array}$ & $\begin{array}{c}0.119 \\
(0.186)\end{array}$ & $\begin{array}{c}0.182 \\
(0.169)\end{array}$ & $\begin{array}{l}-1.636 \\
(2.037)\end{array}$ & $\begin{array}{l}-1.126 \\
(2.013)\end{array}$ & $\begin{array}{l}-1.679 \\
(2.490)\end{array}$ & $\begin{array}{l}-1.194 \\
(2.014)\end{array}$ \\
\hline bank_grgdppc_1214 & $\begin{array}{c}-0.018 \\
(0.016)\end{array}$ & $\begin{array}{l}-0.015 \\
(0.016)\end{array}$ & $\begin{array}{c}-0.022 \\
(0.015)\end{array}$ & $\begin{array}{l}-0.016 \\
(0.015)\end{array}$ & $\begin{array}{c}0.067 \\
(0.270)\end{array}$ & $\begin{array}{c}0.117 \\
(0.266)\end{array}$ & $\begin{array}{c}0.063 \\
(0.308)\end{array}$ & $\begin{array}{c}0.110 \\
(0.267)\end{array}$ \\
\hline Constant & $\begin{array}{c}1.339 \\
(1.926)\end{array}$ & $\begin{array}{c}1.007 \\
(1.932)\end{array}$ & $\begin{array}{c}1.892 \\
(1.998)\end{array}$ & $\begin{array}{c}1.143 \\
(1.920)\end{array}$ & $\begin{array}{l}88.955^{* *} \\
(34.291)\end{array}$ & $\begin{array}{l}84.601^{* *} \\
(33.276)\end{array}$ & $\begin{array}{l}89.320^{* *} \\
(36.103)\end{array}$ & $\begin{array}{l}85.181^{* *} \\
(33.356)\end{array}$ \\
\hline$N$ & 117 & 117 & 117 & 117 & 87 & 87 & 87 & 87 \\
\hline adj. $R^{2}$ & 0.01 & 0.01 & 0.01 & 0.01 & 0.37 & 0.37 & 0.37 & 0.37 \\
\hline $\mathrm{F}$ & 2.31 & 2.34 & 2.36 & 2.31 & 5.74 & 5.69 & 7.22 & 6.10 \\
\hline Weak id test & & 774.62 & 88.74 & 731.38 & & 789.42 & 112.77 & 530.92 \\
\hline Overidentification test & & 0.00 & 0.00 & 1.53 & & 0.00 & 0.00 & 0.13 \\
\hline
\end{tabular}

